\title{
Induced Resistance Responses in Maize
}

\author{
Shericca W. Morris, ${ }^{1}$ Bernard Vernooij, ${ }^{1}$ Somkiat Titatarn, ${ }^{2}$ Mark Starrett, ${ }^{1}$ Steve Thomas, ${ }^{1}$ \\ Curtis C. Wiltse ${ }^{3}{ }^{2}$ Richard A. Frederiksen, ${ }^{4}$ Amornrut Bhandhufalck, ${ }^{5}$ Scot Hulbert, ${ }^{6}$ \\ and Scott Uknes ${ }^{1}$ \\ ${ }^{1}$ Seeds Biotechnology Research Unit, Novartis Inc., P.O. Box 12257, Research Triangle Park, NC 27709, \\ U.S.A.; ${ }^{2}$ Branch of Field Crop Disease, Plant Pathology and Microbiology Division, Department of Agri- \\ culture, Bangkhen, Bangkok 10900, Thailand; ${ }^{3}$ Department of Soil and Crop Sciences and ${ }^{4}$ Department \\ of Plant Pathology and Microbiology, Texas A\&M University, College Station 77843, U.S.A.; ${ }^{5}$ Novartis \\ Ltd., Donmuang, Bangkok 10210, Thailand; and ${ }^{6}$ Department of Plant Pathology, Kansas State Univer- \\ sity, Manhattan 66506, U.S.A. \\ Accepted 12 March 1998.
}

\begin{abstract}
Systemic acquired resistance (SAR) is a widely distributed plant defense system that confers broad-spectrum disease resistance and is accompanied by coordinate expression of the so-called SAR genes. This type of resistance and SAR gene expression can be mimicked with chemical inducers of resistance. Here, we report that chemical inducers of resistance are active in maize. Chemical induction increases resistance to downy mildew and activates expression of the maize PR-1 and PR-5 genes. These genes are also coordinately activated by pathogen infection and function as indicators of the defense reaction. Specifically, after pathogen infection, the PR-1 and PR-5 genes are induced more rapidly and more strongly in an incompatible than in a compatible interaction. In addition, we show that monocot lesion mimic plants also express these defenserelated genes and that they have increased levels of salicylic acid after lesions develop, similar to pathogeninfected maize plants. The existence of chemically inducible disease resistance and PR-1 and PR-5 gene expression in maize indicates that maize is similar to dicots in many aspects of induced resistance. This reinforces the notion of an ancient plant-inducible defense pathway against pathogen attack that is shared between monocots and dicots.
\end{abstract}

Additional keywords: activator chemical, BTH, INA, pathogenesis-related.

Plants resist pathogen attack or slow down pathogen growth by mobilizing a variety of biochemical and molecular defenses (Bowles 1990). These responses include synthesis of various small molecules (e.g., toxic phytoalexins), as well as deposition of callose around the penetration site to strengthen the cell wall. Cell collapse around the site of infection, known as the hypersensitive response (HR), also occurs and is be-

Corresponding author: Bernard Vernooij

E-mail: bernard.vernooij@seeds.novartis.com

Present address of Scott Uknes: Paradigm Genetics, P.O. Box 14528, Research Triangle Park, NC 27709, U.S.A.

Nucleotide and/or amino acid sequence data are to be found at the GenBank data base as accession numbers U82200 and U82201. lieved to aid in localizing the pathogen. There is also evidence for production of active oxygen species that aid in cell wall strengthening and in attacking the pathogen (Mehdy 1994; Baker and Orlandi 1995). In addition, a number of plant species have been shown to develop systemic acquired resistance (SAR) in response to pathogen infection. In this response, the initial infection by a necrotizing pathogen results in a plant with increased systemic disease resistance to a broad spectrum of pathogens (Ross 1961a, 1961b; Kuc 1982; Ryals et al. 1994, 1996). A well-studied SAR system is tobacco, in which local inoculation with tobacco mosaic virus (TMV) induces resistance to such pathogens as Cercospora nicotianae, Peronospora tabacina, Phytophthora nicotianae var. parasitica (a.k.a. Phytophthora parasitica var. nicotianae) (all fungi), Pseudomonas syringae pv. tabaci (a bacterium), and TMV (Ross 1961a, 1961b; Kuc 1982; Ward et al. 1991; Ryals et al. 1996).

The onset of SAR correlates with the expression of SAR genes in the infected as well as the uninfected (systemic) tissues (Ward et al. 1991). The SAR genes include the pathogenesis-related (PR) protein genes (Ward et al. 1991). The SAR genes of tobacco include several glucanases and chitinases that likely work as antifungal enzymes during an infection. Indeed, evidence is accumulating that SAR genes are directly involved in establishing the disease-resistant state of infected plants. Transgenic tobacco plants constitutively over-expressing SAR-type genes exhibit enhanced pathogen resistance. For example, in tobacco, constitutive expression of a bean chitinase results in enhanced disease resistance against Rhizoctonia solani, whereas overexpression of PR-1a, as well as SAR 8.2, leads to enhanced disease resistance to two oomycete pathogens (Broglie et al. 1991; Alexander et al. 1993; Uknes et al. 1996).

Recently, progress has been made in dissecting the SAR signal transduction pathway. Multiple mutants have been isolated that are affected in this pathway (Lawton et al. 1993; Dietrich et al. 1994; Cao et al. 1994; Bowling et al. 1994; Weymann et al. 1995), and the cloning of the first of these genes has been reported (Cao et al. 1997; Ryals et al. 1997). One class of Arabidopsis thaliana mutants altered in the SAR pathway is a subset of so-called lesion mimic mutants. These plants have lesions that are histologically similar to disease lesions. However, they develop in the absence of pathogen 
infection. After lesions form, these so-called $l s d$ (lesion simulating disease) and some acd (accelerated cell death) plants display enhanced resistance to pathogen infection. They also express SAR genes and have elevated levels of salicylic acid (SA; see below), a situation reminiscent of biologically induced SAR (Dietrich et al. 1994; Greenberg et al. 1994; Weymann et al. 1995).

It was first recognized in 1990 that plants accumulate high levels of SA after pathogen infection (Malamy et al. 1990; Métraux et al. 1990). Subsequently, it was shown that plants that degrade SA, due to the presence of the bacterial gene for salicylate hydroxylase, do not show SAR in response to pathogen infection, nor an increase in SAR gene expression in systemic tissues (Gaffney et al. 1993; Lawton et al. 1995; Friedrich et al. 1995). These latter results show that SA accumulation is essential for the development of SAR. It has been postulated that SA is the phloem-mobile, long-distance signal that travels through the plant and induces systemic resistance, but this issue is far from settled (Rasmussen et al. 1991; Vernooij et al. 1994; Shulaev et al. 1995; Chasan 1995; Mölders et al. 1996; Pallas et al. 1996).

It has been known for a long time that SA treatment induces disease resistance and SAR gene expression in plants (White 1979; Ward et al. 1991). Besides SA, other chemical inducers of disease resistance in plants have been described, including 2,6,-dichloroisonicotinic acid (INA) and benzo(1,2,3)thiadiazole-7-carbothioic acid S-methyl ester (BTH) (Métraux et al. 1991; Kessmann et al. 1993; Görlach et al. 1996; Friedrich et al. 1996; Lawton et al. 1996). Plant defense activation with these known plant inducers results in resistance to the same spectrum of diseases as biologically induced SAR, in both tobacco and A. thaliana (Vernooij et al. 1995; Friedrich et al. 1996; Lawton et al. 1996). In addition, INA and BTH activate the same spectrum of SAR genes as is observed during patho- gen-induced SAR (Ward et al. 1991; Uknes et al. 1992, 1993; Vernooij et al. 1995; Friedrich et al. 1996; Lawton et al. 1996). These results, combined with the observation that INA and BTH do not have any observed, direct, antimicrobial activity, led to the conclusion that chemical inducers are activators of the plant's own defense system. Further evidence for this came from the observation that an A. thaliana mutant defective in SAR is also insensitive to chemical inducers (Delaney et al. 1995; Ryals et al. 1997). Thus, both SAR and chemically induced resistance share at least in part the same pathway.

Monocots provide the top three staples in the world: rice, wheat, and maize. Diseases are known to reduce yields in these crops and, especially in wheat, there is a significant reliance on agrochemicals to control disease (Oerke et al. 1994). There are few published reports on biologically induced SAR in monocots. These include rice, where infection by Pseudomonas syringae pv. syringae was shown to lead to systemic protection against leaf blast disease (Smith and Métraux 1991). In spring barley, an initial local infection with powdery mildew was shown to cause increased protection against reinfection with the same organism on other leaves of the same plant (Hwang and Heitefuss 1992).

Only recently have there been investigations into induced resistance for controlling diseases in monocots with defined chemicals. In wheat, BTH induces enhanced, season-long resistance to Erisyphe graminis f. sp. tritici, the causal agent of powdery mildew. BTH is also effective in inducing resistance to the leaf rust fungus Puccinia recondita and septoria leaf spot. In the field, this chemical activator led to an $18 \%$ increase in yield over the nontreated control (Görlach et al. 1996). In rice, BTH treatment of seedlings also gives seasonlong protection against Magnaporthe grisea, the causal agent of rice blast (Görlach et al. 1996). No further details have been published on the effect of BTH in rice. At the molecular

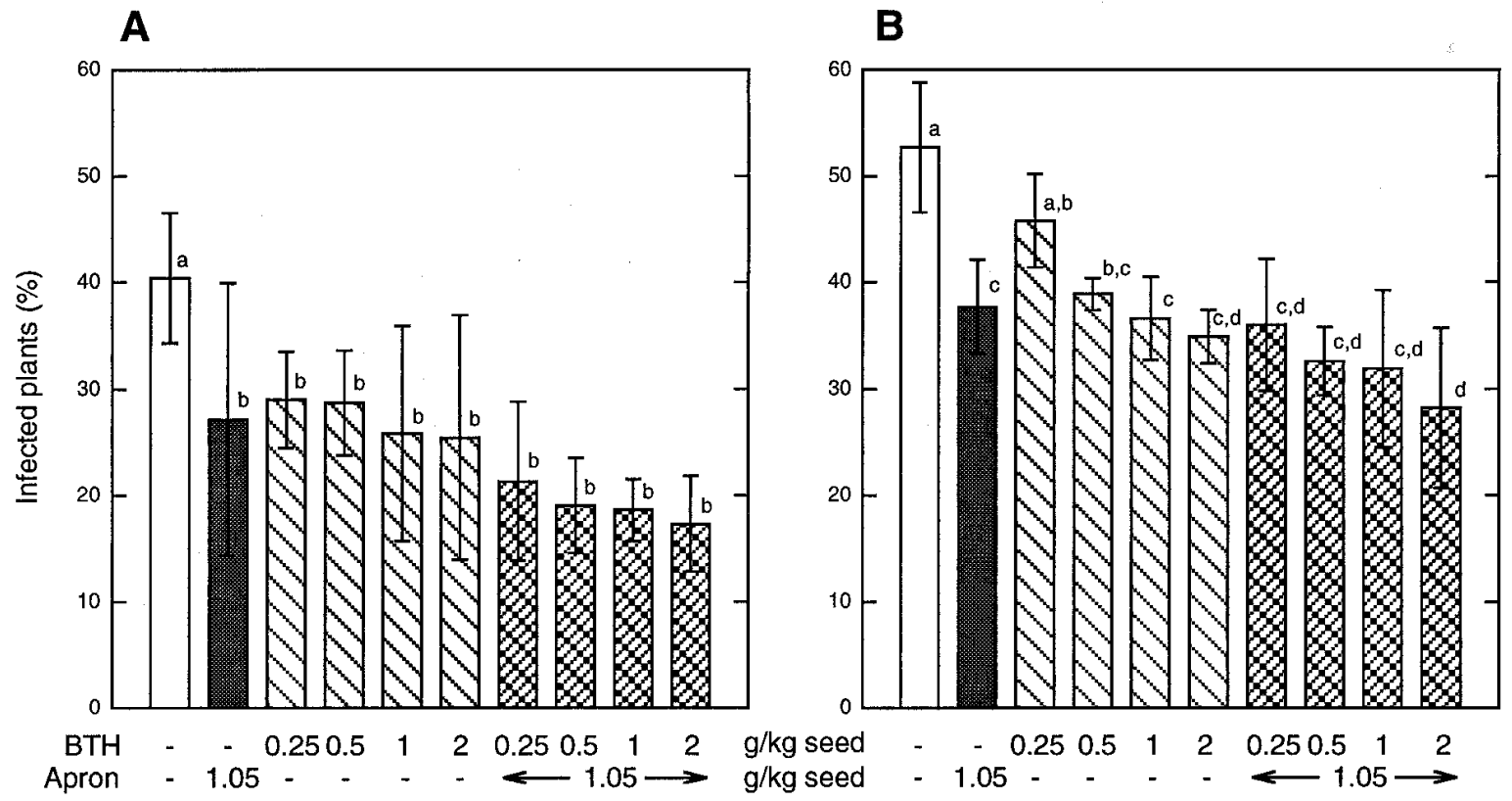

Fig. 1. Benzo(1,2,3)thiadiazole-7-carbothioic acid S-methyl ester (BTH) induces resistance to downy mildew in maize. Maize seeds treated with BTH and/or Apron were planted in fields with high levels of natural infestation. A and $\mathbf{B}$, Results of two separate experiments. Number of plants with visible disease symptoms was scored 40 days after planting; averages \pm standard deviation are shown. Bars with identical letters are not significantly different from each other (Duncan's $t$ test at $P=0.05$ ). 
level, BTH was shown to induce a set of genes in wheat, similar to the coordinate induction of the SAR genes in tobacco and $A$. thaliana. The BTH-inducible genes were also inducible by pathogen infection, but few were homologous to SAR genes that have been described in dicots (Görlach et al. 1996; Friedrich et al. 1996; Lawton et al. 1996). In another studied cereal, barley, INA was shown to induce resistance to powdery mildew, which was accompanied by induction of PR-1 and other defense-related genes (Wasternack et al. 1993; Kogel et al. 1994). Thus, evidence is accumulating that monocots and dicots share similar inducible defense pathways.

We are interested in pathogen defense mechanisms in maize. In this paper we report on chemically induced resistance and expression of defense-related genes in maize. In maize, BTH induces resistance to downy mildew and, like INA and SA, it induces PR-1 and PR-5 gene expression. Following pathogen infection and in lesion mimic mutants, ex-

Table 1. Benzo(1,2,3)thiadiazole-7-carbothioic acid S-methyl ester (BTH) induces resistance to downy mildew in the greenhouse ${ }^{z}$

\begin{tabular}{lcc}
\hline Maize genotype & Treatment & $\begin{array}{c}\text { Mean disease } \\
\text { incidence (\%) }\end{array}$ \\
\hline Sweet G-90 (susceptible) & 0 g of BTH per kg of seed & $39 \% \mathrm{a}$ \\
& $1 \mathrm{~g}$ of BTH per kg of seed & $17 \% \mathrm{~b}$ \\
TAMU 601*625 & - & $13 \% \mathrm{~b}$ \\
$\quad$ (resistant check) & - & 12 \\
LSD $(P<0.05)$ & - & 12 \\
\hline
\end{tabular}

${ }^{\mathrm{z}}$ Maize seeds treated with BTH were planted in pots, and the emerged seedlings were inoculated with spores of Peronosclerospora sorghi pathotype 1. Number of plants with visible disease symptoms was scored 5 to 6 days later. Numbers with identical letters are not significantly different from each other at $P=0.05$ (LSD $=$ least significant difference). pression of these genes is elevated, as is the level of SA. In an incompatible interaction with rust, disease resistance is correlated with a rapid and strong induction of the defense-related genes. However, in a compatible maize-rust interaction, where disease is the outcome, these genes were induced slowly. Our results demonstrate that the phenomenon of induced resistance and associated gene expression in maize shows striking similarities to the dicot situation.

\section{RESULTS}

Various chemicals have been described that induce resistance to disease in dicots and in monocots. The induced resistance response is effective against a spectrum of diseases and, in dicots, is accompanied by coordinate expression of the socalled SAR genes. We set out to investigate induced resistance and defense-related gene expression in maize.

\section{BTH-induced resistance in maize.}

For field tests, BTH-treated maize seeds were planted in downy-mildew-infested soil and plants were rated for disease 40 days after planting. As controls, untreated seeds and seeds treated with the fungicide Apron (active ingredient metalaxyl) were planted. In both experiments, BTH was effective in reducing disease, as shown in Figure 1. At $0.25 \mathrm{~g}$ of BTH per $\mathrm{kg}$ of seed, a reduction in disease incidence was observed that was significantly different from the nontreated control in the first experiment only. Application of 1 or $2 \mathrm{~g}$ of BTH per $\mathrm{kg}$ of seed, however, induced a significant increase in disease resistance in both experiments, similar to the level of resistance induced by the Apron fungicide treatment. At $2 \mathrm{~g}$ of BTH per $\mathrm{kg}$ of seed, up to a $37 \%$ decrease in disease could be achieved

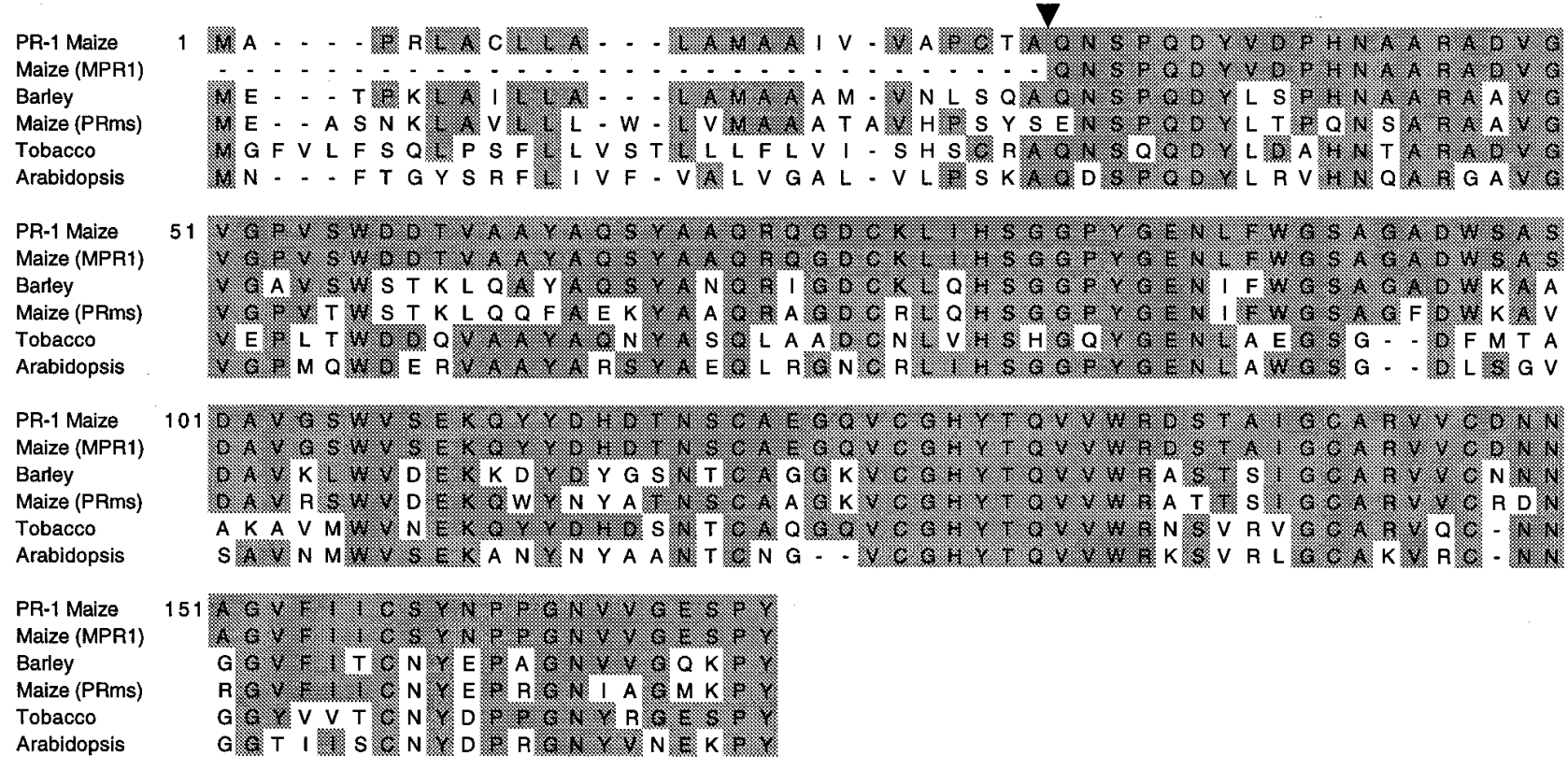

Fig. 2. Alignment of the deduced maize PR-1 protein sequence (PR-1 Maize) with homologous sequences. The most homologous monocot sequen ces were identified by data base searches with the Blast algorithm, whereas the Arabidopsis thaliana and tobacco sequences are shown as examples of dicot systemic acquired resistance (SAR) genes. Origin of sequences: maize (MPR1): A33155 (Gillikin et al. 1991); barley: S37166 (Bry ngelsson et al. 1994); maize (PRms): Q00008 (Casacuberta et al. 1991); tobacco: X06930 (Pfitzner and Goodman 1987); A. thaliana: M90508 (Uknes et al. 1992$)$. Shaded amino acids are identical to those in the PR-1 Maize sequence. Arrow indicates position of putative leader cleaveage site in PR-1 Maize. GenBank accession number is U82200. 
(Fig. 1A). In addition, when seed was treated with a mix of $\mathrm{BTH}$ and Apron, there was a further reduction in disease of up to $57 \%$ over the nontreated controls (Fig. 1A), indicating that the two compounds may act synergistically.

In a downy mildew disease test in the greenhouse, BTH induced even better protection, as shown in Table 1. BTH treatment (at $1 \mathrm{~g}$ of BTH per $\mathrm{kg}$ of seed), reduced the incidence of disease from 39 to $17 \%$. This induced level of protection was similar to the genetic resistance present in the resistant check (Table 1). Thus, a resistance-inducing chemical can achieve a significant reduction in downy mildew disease incidence.

\section{Isolation of defense genes from maize.}

To determine if induced resistance in maize is accompanied by changes in gene expression similar to that seen in other plants, we isolated two homologs of known dicot SAR genes. Maize PR-1 and PR-5 genes were isolated from a cDNA library of BTH-treated leaves with homologous probes (see Materials and Methods for further details). Near-full-length clones were isolated that contain the entire coding sequences, the entire $3^{\prime}$ untranslated regions, short poly A tails, and short $5^{\prime}$ untranslated sequences. The deduced protein sequences are shown in Figures 2 and 3 in alignments with homologous sequences. Both predicted proteins appear to have leader sequences that presumably direct the mature proteins to the endoplasmic reticulum (see below). The predicted size of the mature maize PR-1 polypeptide is $15 \mathrm{kDa}$. It is acidic, with a predicted $\mathrm{pI}$ of 4.4. The predicted size of the mature maize PR5 polypeptide is $15.7 \mathrm{kDa}$, while the predicted $\mathrm{pI}$ is 4.6 , indicating that, as with maize PR-1, this too is an acidic protein.

The PR-1 cDNA codes for a protein that is identical (with the exception of the $\mathrm{N}$-terminal leader sequence) to the protein that was isolated from infected corn roots and subsequently sequenced in its entirety by Gillikin et al. (1991). As shown in Figure 2, a comparison of the cDNA deduced protein and the root protein indicates that the PR-1 protein is synthesized as a precursor protein with a leader that presumably directs the mature protein to the extracellular space. The predicted leader cleavage site conforms well to the published consensus sequence for eukaryotic cleavage sites and is also identical to the homologous cleavage site in the A. thaliana PR-1 protein (Von Heijne 1986; Uknes et al. 1992; see Figure 2).

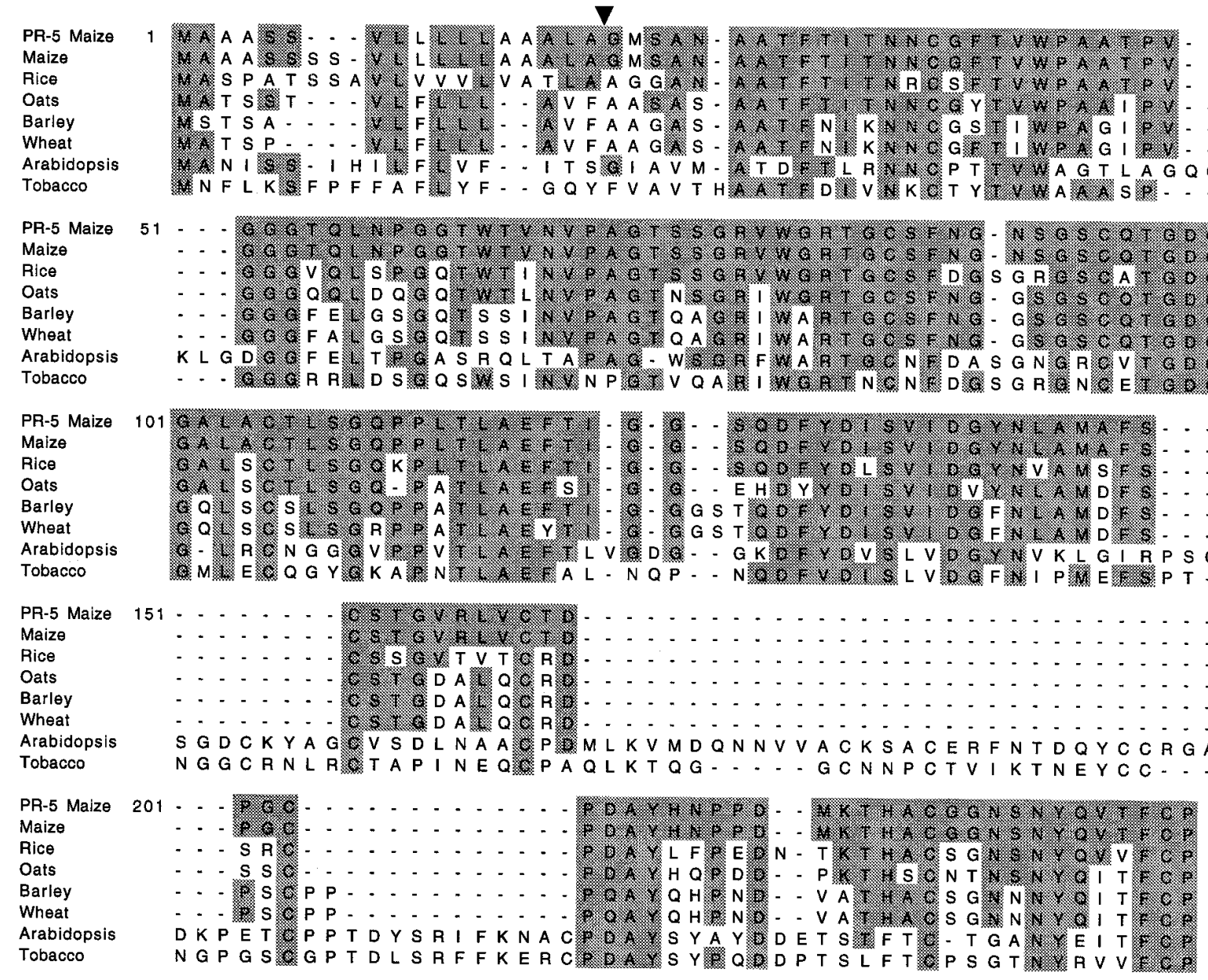

Fig. 3. Alignment of the deduced maize PR-5 protein sequence (PR-5 Maize) with homologous sequences. The most homologous monocot sequences were identified by data base searches with the Blast algorithm, whereas the Arabidopsis thaliana and tobacco sequences are shown as examples of dicot systemic acquired resistance (SAR) genes. Origin of sequences: maize: 1906392A (Frendo et al. 1992); rice: P31110 (Reimmann and Dudler 1993) oats: L39777 (Lin et al. 1996); barley: P32937 (Hahn et al. 1993); wheat: P27357 (Rebmann et al. 1991); A. thaliana: M90510 (Uknes et al. 1992); tobacco: P13046 (Payne et al. 1988). Shaded amino acids are identical to those in the PR-5 Maize sequence. Arrow indicates position of putative leader cleaveage site in PR-5 Maize. GenBank accession number is U82201. 
The conservation of the PR-1 protein sequences among monocots and between maize and dicots is very high, with the exception of the leader sequences (Fig. 2). The gene that is most homologous to maize PR-1 is found in barley, which was used as the probe in the screen. Maize PR-1 also shows homology to a basic PR-1-like sequence, PRms (Casacuberta et al. 1991), that is expressed in maize seeds, but the latter gene is not inducible in leaves by chemical activators (data not shown). These two maize PR-1 genes do not cross-hybridize under stringent conditions (data not shown). Additional maize PR-1 genes with sequences that are very homologous to the PR-1 sequence reported here (Andrée Genez, personal communication) have been isolated, indicating that maize has a PR-1 gene family with multiple members. Southern blot analysis confirmed this (data not shown). Finally, the maize PR-1 sequence shows high homology with tobacco and $A$. thaliana PR-1. The likely homology with tobacco PR-1a was noted before, as an antiserum to tobacco PR-1a was shown to cross-react with the maize PR-1 protein (Gillikin et al. 1991). This is not surprising, as there is $56 \%$ identity between the amino acid sequences of maize and tobacco PR-1.

The protein sequence deduced from the PR-5 cDNA sequence is shown in Figure 3. The most likely signal sequence cleavage site is indicated in Figure 3 and was inferred from the data tabulated by Von Heijne (1986). This putative cleavage site is not homologous to the cleavage site in A. thaliana PR-5 (which is between positions 23 and 24: MA $\vee$ TD; Uknes et al. 1992), as the homologous site in maize PR-5 does not conform well to the consensus for such sites (Von Heijne
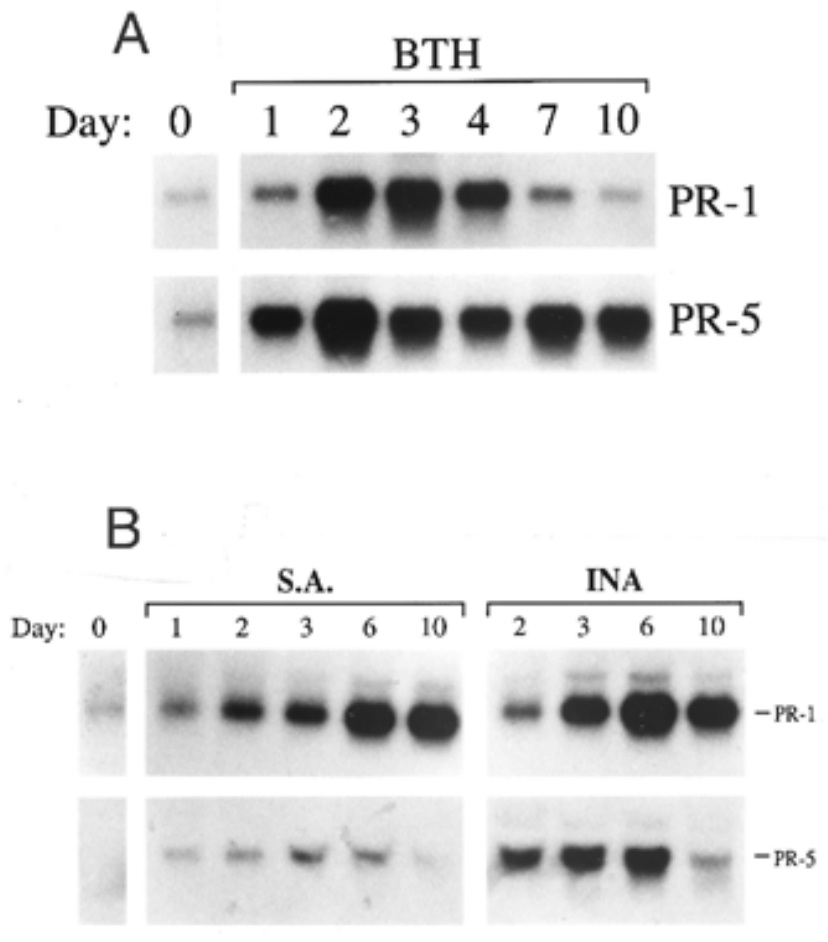

Fig. 4. Time course of PR-1 and PR-5 gene expression in chemically treated maize plants. A, PR-1 and PR-5 mRNA levels in leaf tissue are shown following spray treatment of leaves with $1.2 \mathrm{mM}$ benzo(1,2,3) thiadiazole-7-carbothioic acid S-methyl ester (BTH). B, Time course of PR-1 and PR-5 gene expression in 2,6,-dichloroisonicotinic acid (INA, $1.3 \mathrm{mM})$ and salicylic acid $(\mathrm{SA}, 50 \mathrm{mM})$ treated maize.
1986). If the A. thaliana type cleavage site was used in the maize PR-5 preprotein, a slightly smaller protein would be produced $(15.2 \mathrm{kDa})$, but with the same $\mathrm{pI}(4.6)$ as predicted above.

Maize PR-5 belongs to the thaumatin family of proteins. This family includes several protein groups, including the PR5-like proteins described in dicots and monocots. Maize PR-5 is most homologous to other monocot PR-5-like proteins (Fig. $3)$. It is nearly identical to another maize PR-5 sequence, with which it differs by only two amino acids in the leader (Frendo et al. 1992). These genes may be alleles, as they were isolated from different maize genotypes. The next highest homology is with the rice gene that was used to isolate the maize cDNA. The alignment in Figure 3 shows that maize PR-5 has significant homology to the $A$. thaliana PR-5 sequence and the major form of PR-5 from tobacco. These dicot sequences are characterized by large insertions relative to the monocot sequences. However, not all monocot sequences of the thaumatin family have this deletion, such as for example the bifunctional $\alpha$ amylase/proteinase inhibitor gene and the highly homologous zeamatin gene from maize (Richardson et al. 1987; Frendo et al. 1992; Huynh et al. 1992; and data not shown).

\section{Chemical induction of PR-1 and PR-5 genes in maize.}

$\mathrm{SA}$ is an endogenous signal molecule in dicots involved in SAR and SAR gene expression (Gaffney et al. 1993). BTH and INA are synthetic chemicals capable of inducing disease resistance and SAR gene expression in several dicots, and disease resistance in four monocots (Métraux et al. 1991; Kessmann et al. 1993, 1994; Kogel et al. 1994; Vernooij et al. 1995; Görlach et al. 1996; Friedrich et al. 1996; Lawton et al. 1996). We tested these compounds for their ability to induce PR-1 and PR-5 gene expression in maize. The maize PR-1 gene shown in Figure 2 is a member of a multigene family and the same may be true for PR-5. Our experiments do not reveal which member(s) of the family are induced in the experiments reported below.

We found BTH to be particularly effective in inducing PR-1 and PR-5 mRNA in maize. Following BTH treatment (1.2 $\mathrm{mM}$ ), the PR-1 and PR-5 genes were coordinately induced and peaked at 2 to 3 days after application, as shown in Figure 4A. PR-1 mRNA levels decayed to near background levels by 10 days after application, while the PR-5 levels remained elevated. Two to 3 days after application, induction levels were typically 15 -fold over the water control, as determined by PhosphorImager analysis of the blots. Induction of PR-1 and PR-5 by BTH was also different in another way: PR-5 was reinducible after mRNA levels had decreased, whereas the PR-1 mRNA levels were not (data not shown).

Figure 4B shows PR-1 and PR-5 gene expression levels in response to SA and INA. Both chemicals were capable of inducing PR-1 and PR-5 gene expression, but they were not as effective as BTH at the doses used. Maximum gene expression levels were typically reached at approximately 6 days after application of SA and INA. Interestingly, the duration of increased gene expression was longer after SA and INA treatment than after BTH treatment. Whether the delayed and prolonged gene expression resulted from a slower and more prolonged uptake of SA and INA by the leaves is not clear. SA was typically slightly less effective in inducing PR-1 mRNA than was INA, but was also more variable (data not shown). 
PR-1 mRNA induction levels by SA and INA were up to fiveand ninefold, respectively, over the water-treated tissues. In the experiment shown in Figure 4B, SA was rather ineffective in inducing PR-5 mRNA accumulation, but this was not always the case.

\section{Pathogen infection of susceptible and resistant maize: 1. Incompatible interactions - common rust.}

In maize, common rust, caused by Puccinia sorghi, is a disease that is characterized by the formation of rust pustules on leaves in productively infected plants. This is an economically important leaf disease of corn, which is controlled by a combination of polygenic and single-gene resistances. P. sorghi spores that germinate on the leaf of a susceptible plant infect the leaf and form feeding structures (haustoria) in plant cells. The ensuing fungal growth and development result in disease and eventually in sporulation, approximately 5 days after infection (see Figure 5, left photo in the lower panel). A series of alleles of the resistance gene $R p l$ have been identified that confer race-specific resistance against $P$. sorghi biotypes (Hulbert and Bennetzen 1991). Plants that carry the appropriate $R p l$ allele respond to infection with defense reactions, including an HR, resulting in visible lesions. Because these infections never result in sporulation, these interactions are termed incompatible.

We studied PR-1 and PR-5 gene expression in the incompatible interaction between maize and $P$. sorghi biotype IN2. We inoculated two $R p l$ lines, $R p l-A$ and $R p l-D$, that have resistance genes to biotype IN2 (Hulbert and Bennetzen 1991) with IN2 spores and mock inoculated control plants of the same genotypes. Plants were subsequently monitored for resistance responses and defense-related gene expression.

In the IN2-Rp1-D interaction, hypersensitive cell death was observed between 16 and $24 \mathrm{~h}$ after inoculation (Fig. 5). Lesions continued to grow until approximately $48 \mathrm{~h}$ after inoculation, at which time they ceased to enlarge (Fig. 5; and Hu et al. 1996). In Rpl-A plants, the HR was observed between 24 and $48 \mathrm{~h}$ after inoculation (Fig. 5). These lesions were initially smaller than those in $R p 1-D$ plants due to their later emergence, but were typically about the same size as in $R p 1-D$ plants at $48 \mathrm{~h}$ after inoculation. Because the lesions on Rpl-A plants continued to enlarge, the leaves eventually became very necrotic. Neither IN2-infected Rpl-D nor IN2-infected Rpl-A leaves developed rust pustules (Fig. 5).

In IN2-infected $R p 1-D$ plants, the first increase in PR-1 and PR-5 gene expression in infected leaves was detected 8 to 16 $\mathrm{h}$ after inoculation (Fig. 6). This preceded the first visible symptoms of HR. Defense-related gene expression increased strongly while lesions increased in size. After $48 \mathrm{~h}$, when lesions had stopped growing, defense-related gene expression ceased to increase and became more variable, with a downward trend (Fig. 6; and data not shown). Seven days after inoculation, PR-1 and PR-5 mRNA levels were fairly low in these plants (data not shown).

In IN2-infected Rpl-A plants, the HR occurred later than in the $R p l-D$ infected plants and the first increase in PR-1 and PR-5 gene expression was similarly detected later, at around $24 \mathrm{~h}$ after inoculation (Fig. 6). As lesions grew, gene expression also continued to increase. At $72 \mathrm{~h}$ after infection, defense-related gene expression was about as high as at $48 \mathrm{~h}$, and by 7 days after inoculation PR-1 and PR-5 gene expression in
Rpl-A plants showed a small decrease only, presumably because, as lesions were growing, additional cells were becoming affected that subsequently responded with expression of these defense-related genes. Mock inoculated plants (see Figure 7) showed very little if any PR-1 and PR-5 gene expression.

\section{Incompatible interactions - southern corn leaf blight.}

Southern corn leaf blight (SCLB) is a maize leaf disease caused by Bipolaris maydis (also referred to as Helminthosporium maydis and Cochliobolus heterostrophus). In field corn, this disease is a problem in certain regions of the U.S. Polygenic resistance is used to control the disease in the field. PR1 and PR-5 gene expression levels were monitored in two maize genotypes following infection with $B$. maydis spores. Following infection, both genotypes developed HR lesions that continued to enlarge slowly over time. The CG00526 genotype proved to be slightly more resistant than the CG00689 genotype, as evidenced by larger lesions on CG00689 plants (in one experiment, lesions on leaves of CG00526 plants were $3.7 \pm 0.3 \mathrm{~mm}$, and $4.7 \pm 0.5 \mathrm{~mm}$ on CG00689 plants 6 days after infection; and data not shown). We performed Northern (RNA) blot analysis of the PR-1 and PR-5 mRNA levels and found repeatedly that PR-1 and PR-5 mRNA levels are typically undetectable in uninfected CG00689 plants. In uninfected CG00526 plants, however, low yet detectable PR-1 and PR-5 mRNA levels were often observed (S. Morris, unpublished data).

Following pathogen infection, an HR is first visible after about $24 \mathrm{~h}$ in both genotypes. Accumulation of PR-1 and PR5 mRNA is easily detectable 1 day after infection and continues to rise for another 1 to 2 days, as shown in Figure 8. After 3 days, the mRNA levels decline somewhat. In all plants (infected plants and noninfected control plants) PR-1 and PR5 mRNA levels start to rise again at 2 weeks after infection, possibly due to the extended incubation in the growth chamber. The blots in Figure 8 were prepared, hybridized, and washed together (where possible), and exposed for the same length of time. As shown in Figure 8, the levels in CG00526 (the slightly more resistant line) were higher for most of the experiment than in the more susceptible line, CG00689.

The gene expression results of the incompatible interactions, with both common rust and SCLB infections, show that, as in dicots, infection of maize with an avirulent pathogen leads to rapid induction of defense-related gene expression.

\section{Compatible interactions - common rust.}

If a $P$. sorghi-infected maize plant does not express the appropriate $R p l$ allele, the infecting biotype is not recognized, an HR does not develop, and a successful infection (disease) occurs. We studied PR-1 and PR-5 gene expression in compatible interactions between maize and $P$. sorghi biotype KS1 and IN2, using $R p 1$ lines that have no resistance genes to these biotypes (Hulbert and Bennetzen 1991). Plants were inoculated with rust biotypes IN2 or KS1, or mock inoculated and monitored for disease symptoms and PR-1 and PR-5 gene expression.

Infection of all lines ( $R p l-A, R p 1-D$, and $r p l)$ with KS1 resulted in general disease as evidenced by spreading chlorosis, and eventually pustule formation, in the absence of any HR. Similarly, in the compatible interaction between IN2 and $r p 1$, no HR was observed, nor were disease symptoms evident un- 

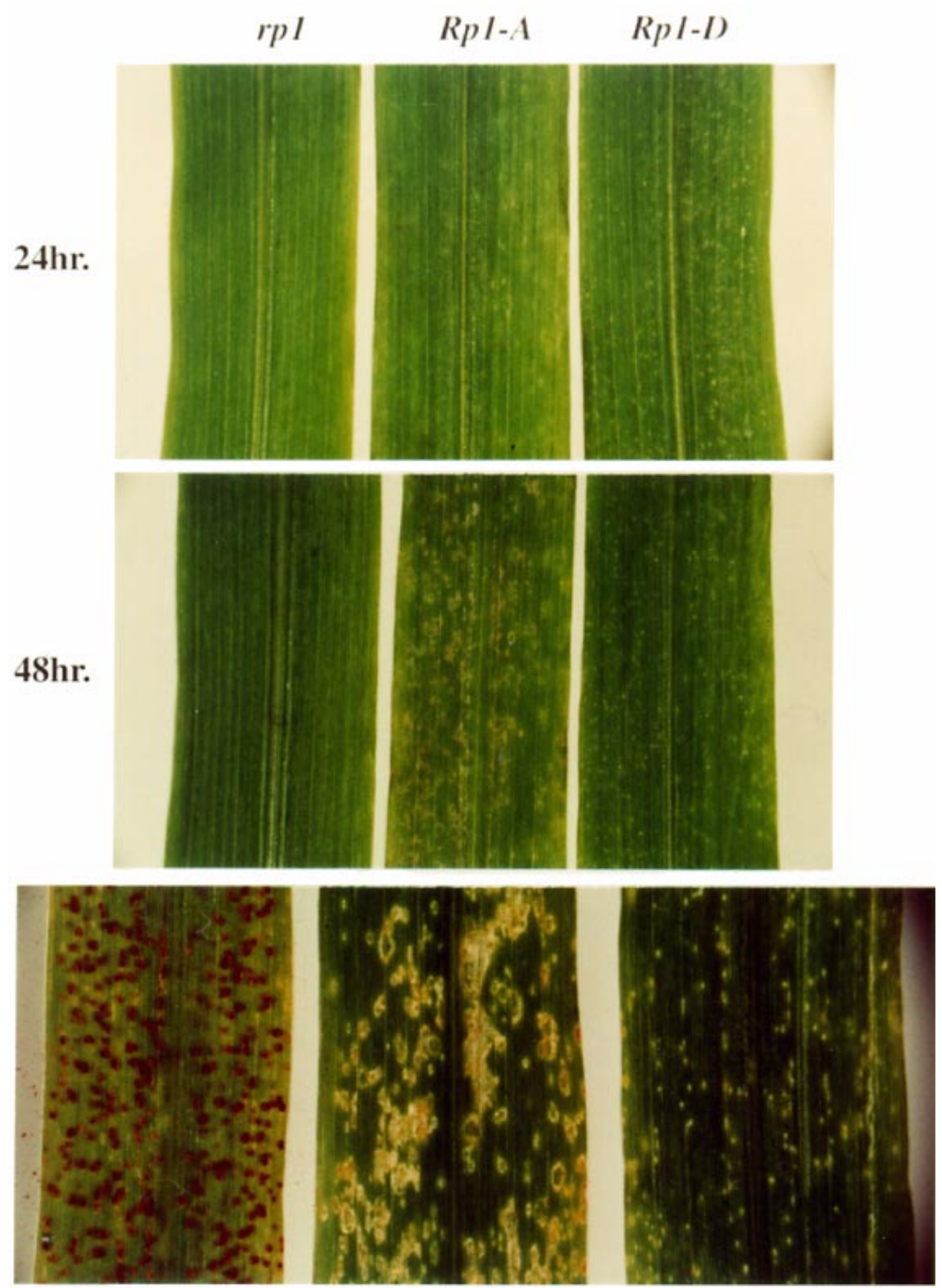

\section{8hr.}

Fig. 5. Phenotypes of rust infected maize. Infection phenotype of rust isolate IN-2 is shown in a compatible (with maize genotype $r p 1$ ) and two incompatible (Rp1-A and Rp1-D) interactions. Time points at which photos were taken: 24 (top), 48 (middle), and 168 (bottom) h after infection. 
til late in infection, with pustule formation occurring approximately 6 days after infection (Fig. 5).

In the compatible interactions, little defense-related gene expression was typically detected until late in the infection (Fig. 7). In all cases, PR-1 and PR-5 gene expression increased slowly over time to levels that were significantly below those seen in the incompatible interaction. KS1 infection of Rpl-D and $r p l$ plants resulted in the highest mRNA accumulation among the compatible interactions, but even here mRNA lev- els were always below those in the incompatible interaction at equivalent time points. The phenomenon of delayed and low defense gene expression in compatible interactions has been known for quite some time (De Wit and van der Meer 1986).

In mock-inoculated plants, PR-1 and PR-5 gene expression was generally low. Significant PR-1 gene expression was only visible in rpl plants at $168 \mathrm{~h}$ after mock inoculation, while there was no significant PR-5 gene expression in mockinoculated plants (Fig. 8).
PR-1

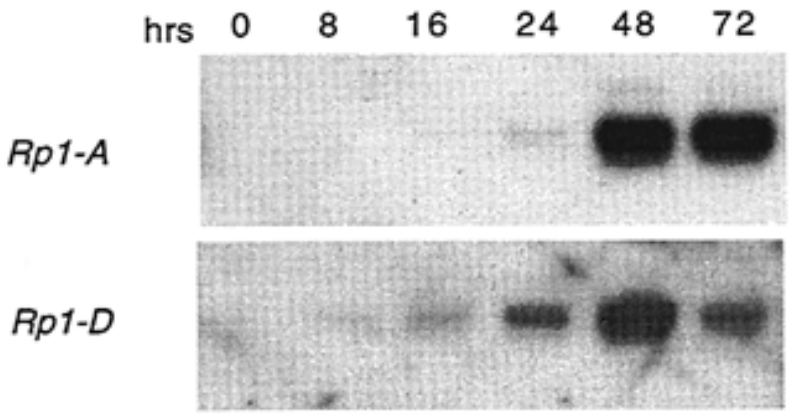

PR-5

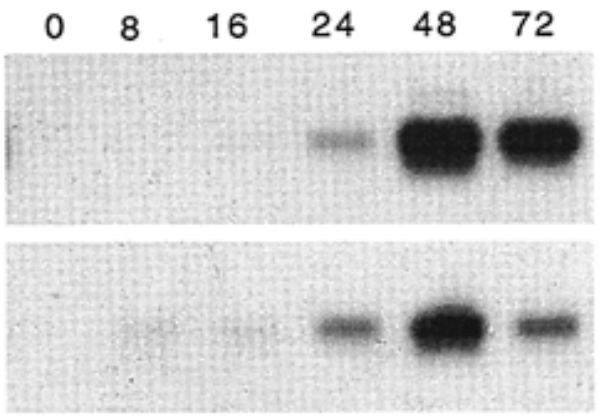

Fig. 6. Time course of maize PR-1 and PR-5 mRNA levels in plants infected with an incompatible common rust isolate, IN2. Inoculated leaf material was harvested at various times after inoculation and analyzed for PR-1 and PR-5 mRNA levels by Northern (RNA) analysis.

compatible

PR-1

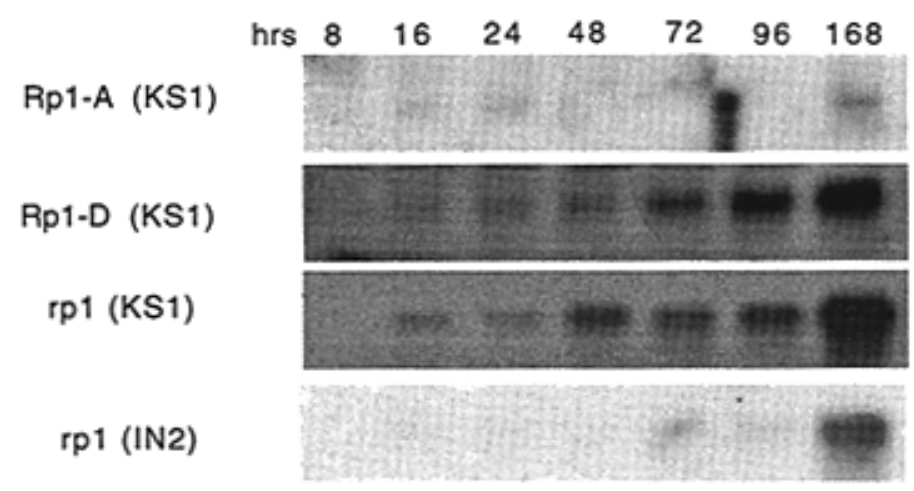

PR-5
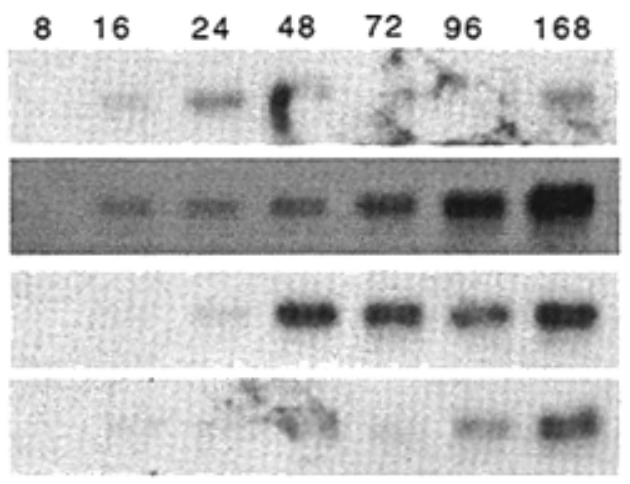

mock
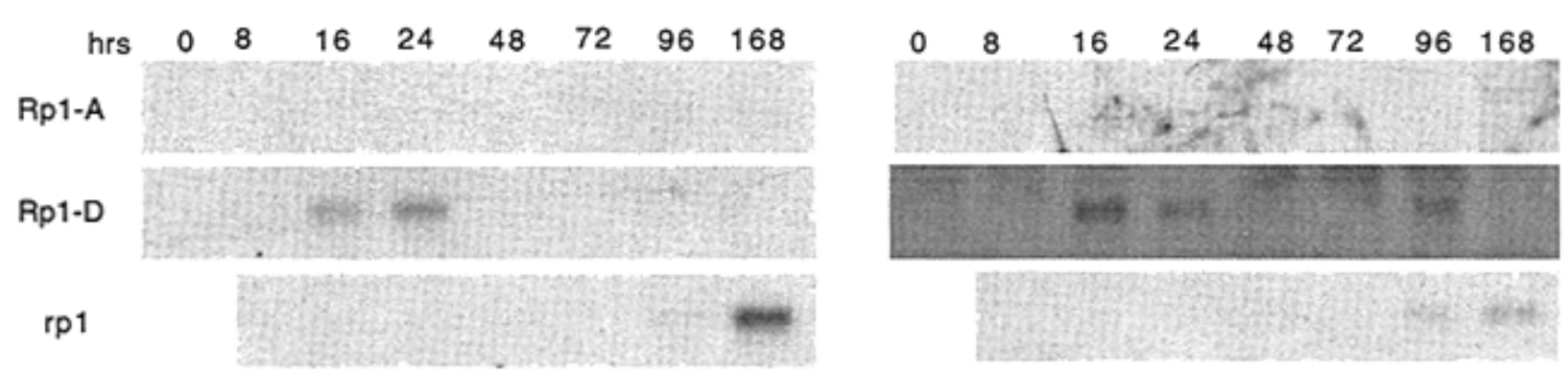

Fig. 7. Time course of maize PR-1 and PR-5 mRNA levels in plants infected with compatible common rust isolates. Inoculated leaf material was harvested at various times after inoculation and analyzed for PR-1 and PR-5 mRNA levels by Northern (RNA) analysis. Maize genotype/infecting rust isolate are indicated to left of each set of Northern panels. Mock inoculated plants were treated with talc only. 
Lesion mimic mutants.

Lesion mimic mutants have been described in a variety of plant species. These plants develop spontaneous lesions that mimic those that occur due to disease (see Walbot et al. 1983; Johal et al. 1995; Dangl et al. 1996). A subset of A. thaliana lesion mimics ( $l s d$ and $a c d 2$ mutants) show increased disease resistance, SA accumulation, and SAR gene expression (Dietrich et al. 1994; Greenberg et al. 1994; Weymann et al. 1995). These plants are believed to carry mutations that lead to increased disease resistance as a result of activation of the SAR pathway.

In maize, many lesion mimics are known (Walbot et al. 1983; Johal et al. 1995). We investigated PR-1 and PR-5 gene expression in 17 lesion mimic lines in the pre-lesion stage, after lesion development but before tasseling (if possible), and again after anthesis. As shown in Figures 9 and 10, background levels of PR-1 gene expression (i.e., the mRNA level in the pre-lesion state) were somewhat variable, but typically low. Upon lesion formation, PR-1 mRNA levels increased dramatically, whether the lesions developed before or after anthesis. The exception to this was the Les 2 line, where the increase was a few fold at most (Fig. 9). When lesions developed before anthesis, a further increase in PR-1 gene expression levels was often observed after anthesis (Figs. 9 and 10). Non-lesion-mimic siblings from the same crosses that gave rise to the lesion mimics did not show any substantial induction of defense-related gene expression before tasseling (data not shown). Two out of three non-lesion-mimic maize lines that were tested for PR-1 gene expression after tasseling did not accumulate PR-1 at that time. The third line did show some PR-1 mRNA accumulation after tasseling, at a level intermediate between that seen in Les 2 and Les 12 after anthesis (data not shown). Thus, most of the 17 lesion mimic lines

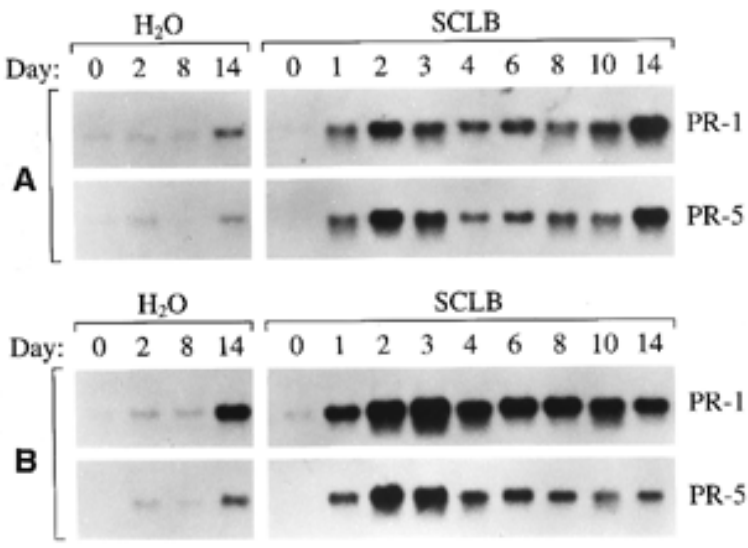

Fig. 8. Time course of PR-1 and PR-5 mRNA levels in southern corn leaf blight (SCLB) infected maize plants. Two genotypes are shown: (A) CG00689 and (B) CG00529. Inoculated leaf material was harvested at various times after inoculation and analyzed for PR-1 and PR-5 mRNA levels by Northern (RNA) analysis.

Fig. 9. PR-1 mRNA levels in maize lesion mimic plants, before lesions developed (prelesion, PL), when lesions developed before tasseling (L1), and after tasseling, with lesions present (L2). Empty L1 lanes indicate that these plants did not express lesions before tasseling and hence were not analyzed at this time point. Exceptions: *, lesions present at this time point but no sample analyzed.
Lesion Mimic PL L1 L2

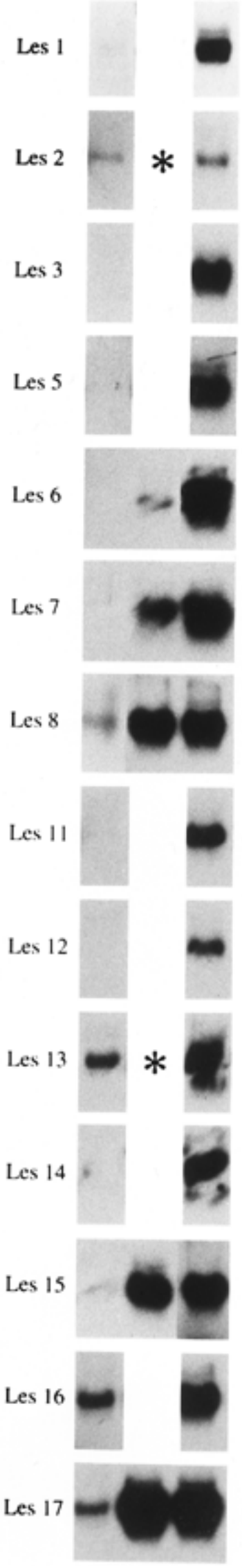



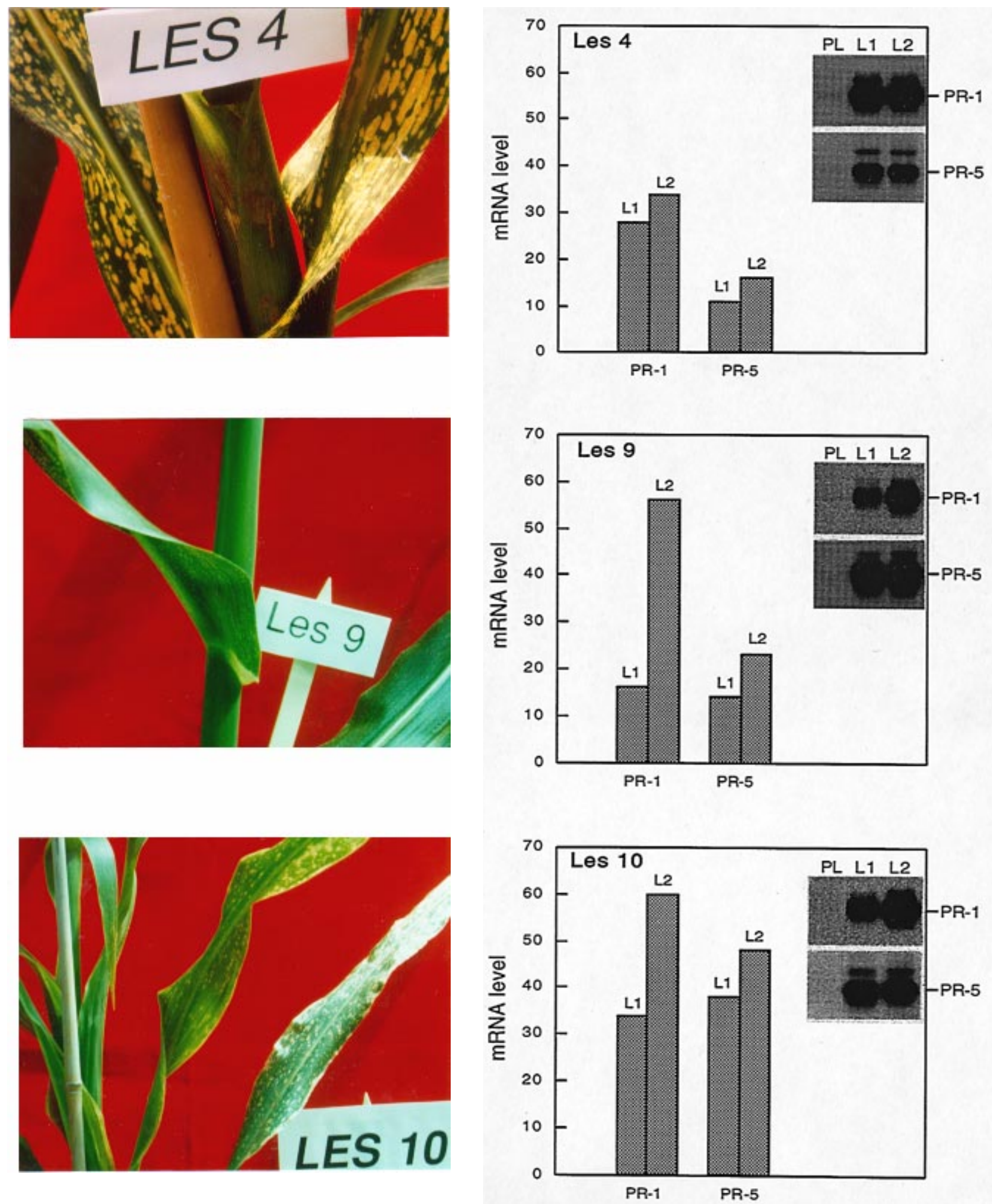

Fig. 10. Visible and molecular phenotypes of maize lesion mimic plants. Lesion phenotypes of Les 4, Les 9, and Les 10 plants are shown. PR-1 and PR5 mRNA levels in leaf tissue of these lesion mimics are shown, prior to lesion formation (PL), after lesions formed (L1), and after anthesis (L2). The mRNA levels are expressed as fold induction of the mRNA level relative to the PL mRNA level. All samples were run on the same gel. 
appear to have post-tasseling PR-1 mRNA levels that are well above those that might be induced by tasseling in wild-type plants. In addition, seven of the Les lines displayed high PR-1 mRNA levels even before tasseling (Figs. 9 and 10).

The visible and molecular phenotypes of the three lesion mimic lines with the largest induction of defense-related gene expression (Les 4, 9, and 10) are shown in Figure 10. In these lines, mRNA levels for PR-1 and PR-5 were analyzed. In all three lines, defense-related gene expression was not observed in the pre-lesion state. Once lesions developed (L1), PR-1 and PR-5 mRNA accumulated, and typically increased after anthesis (L2). In Les 4, PR-1 mRNA levels were increased 33-fold over the pre-lesion state, while they were over 50 -fold increased in Les 9 and Les 10 (Fig. 10). The levels of PR-5 mRNA were also strongly increased in these lesion mimics, albeit not as much as those of PR-1.

This situation is very similar to that observed in A. thaliana $l s d$ and $a c d 2$ lesion mimic plants, where SAR gene expression (PR-1, PR-5) is also greatly increased after lesion development (Dietrich et al. 1994; Greenberg et al. 1994; Weymann et al. 1995). As with infected $A$. thaliana plants, these $A$. thaliana mutants also display increased SA levels. We investigated SA levels in maize lesion mimics, as well as in infected maize plants. Uninfected, non-lesioned maize leaves showed moderate levels of SA (less than $200 \mathrm{ng}$ per $\mathrm{g}$ of fresh weight). Upon infection with Colletotrichum graminicola or B. maydis, the levels of free and total SA increased (Fig. 11). Infection by both of these fungi result in necrotic leaf areas, which affected more leaf area in the CG00689 than the CG00526 genotype (data not shown and see above). This correlated with a larger accumulation of total SA in these more severely affected leaves (Fig. 11). While free SA levels increased moderately in infected leaves (up to 2.6-fold), total SA levels increased over sevenfold in leaves with the more severe symptoms.

After lesions developed in lesion mimic line Les 4, free SA levels increased less than twofold over the pre-lesion state. Total SA levels, however, increased to levels similar to those seen in the C. graminicola-infected leaves of CG00689 (over $1.5 \mu \mathrm{g}$ per $\mathrm{g}$ of fresh weight). Due to the low levels of SA in pre-lesion Les 4 plants, this represented a 20-fold increase over the pre-lesion state (Fig. 11). Thus, maize leaves accumulate SA following infection with incompatible pathogens, as do maize lesion mimic plants after lesions develop. This is similar to the situation in dicots.

We also investigated the histology of lesions that developed on Les 4 plants and lesions on SCLB-infected leaves (HR lesions). Following aniline blue staining, callose deposition at the edges of both types of lesions was visible (Fig. 12). Thus, lesions in lesion mimic plants resemble disease lesions not only at the macroscopic level, but also at the histological level.

Fig. 11. Salicylic acid (SA) levels in leaves of infected and lesion mimic plants. Free and total (free SA plus glucose conjugated SA) SA levels were determined in infected and uninfected tissue from two maize genotypes (CG00689 and CG00526), as well as in leaves from Les 4 plants, before and after lesions (lesion ${ }^{+}$) developed. Ctrl: control tissue from uninfected plants; ALB: tissues infected with Colletotrichum graminicola, causal agent of anthracnose leaf blight; SCLB: tissue infected with Bipolaris maydis, causal agent of southern corn leaf blight.
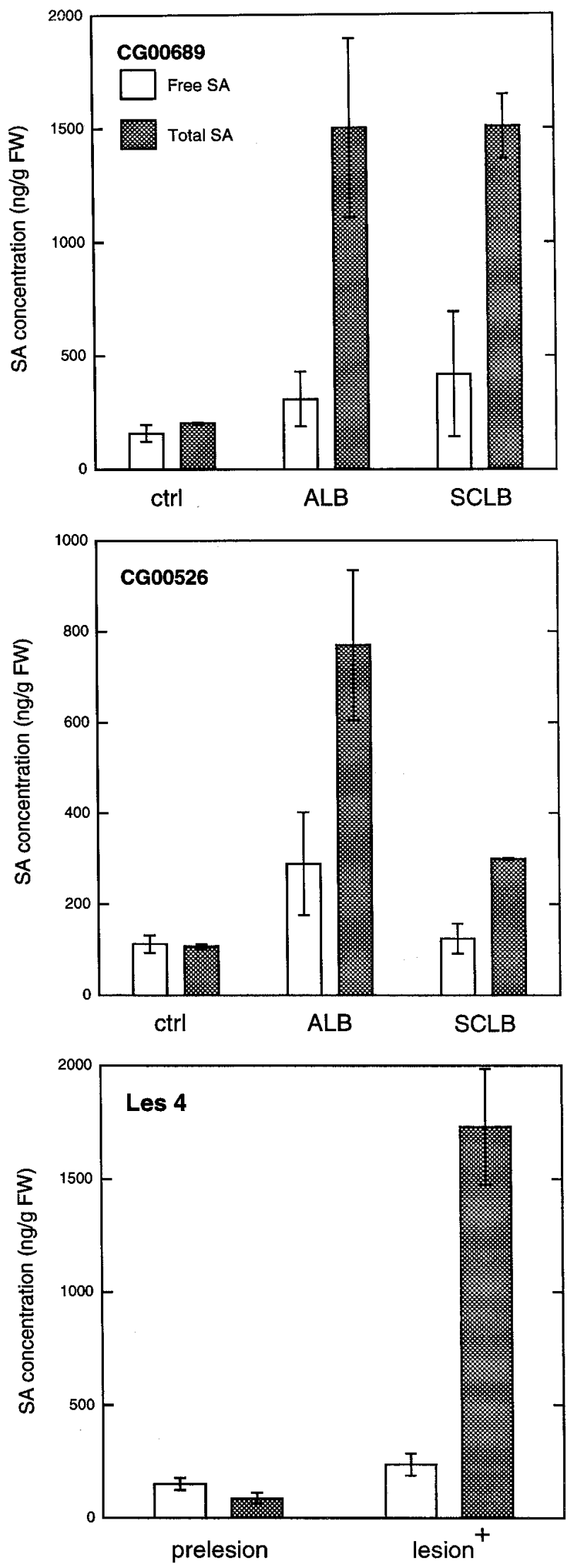


\section{DISCUSSION}

\section{Chemically induced disease resistance in maize.}

Induced resistance has been described in a wide variety of dicots and monocots, with tobacco and A. thaliana as the beststudied examples. In the dicot plant species, chemicals such as $\mathrm{BTH}, \mathrm{SA}$, and INA induce resistance by activating the SAR pathway. The best evidence for this is that these chemicals are unable to induce disease resistance in an A. thaliana mutant blocked in the SAR pathway (Delaney et al. 1995; Ryals et al. 1997).

Under our test conditions, BTH is as effective as a commercially available fungicide, Apron, in inducing resistance to downy mildew in maize (Fig. 1 and Table 1). Since BTH does
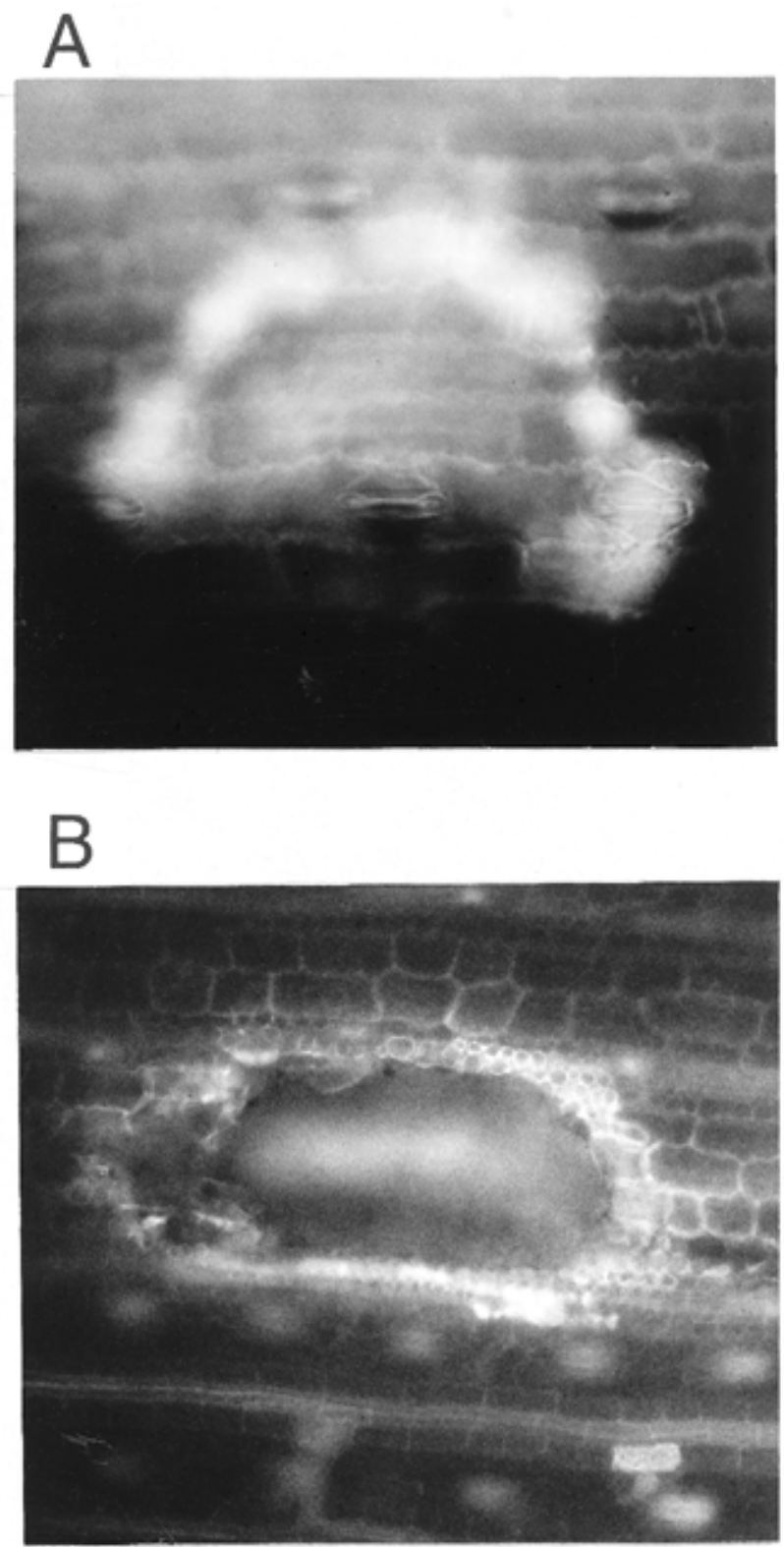

Fig. 12. Callose deposition in lesions of (A) southern corn leaf blight infected plants and (B) Les 4 plants. Leaf sections with lesions were isolated and stained for callose deposition with aniline blue. Callose appears as white staining. not have any known direct antifungal activity (Görlach et al. 1996), it likely acts by activating the endogenous maize defense system, as supported by the observation that BTH induces PR-1 and PR-5 gene expression in maize. The potential synergy between BTH and Apron (Fig. 1) may also be explained by these two chemicals having different modes of action.

Chemical activators of disease resistance in dicots have been known for some time (Métraux et al. 1991; Ward et al. 1991; Uknes et al. 1992; Kessmann et al. 1994; Vernooij et al. 1995; Friedrich et al. 1996; Lawton et al. 1996). They have now also been shown to work in the monocots wheat, rice, barley, and maize (Wasternack et al. 1993; Kessmann et al. 1994; Kogel et al. 1994; Görlach et al. 1996; Lawton et al. 1996; and this report), which includes most of the important food staples for the world's population.

\section{PR-1 and PR-5: structure and expression.}

In a screen of a cDNA library from BTH-treated maize plants, we cloned PR-1 and PR-5 genes that are alleles of, or identical to, previously identified maize PR genes and proteins. These PR-1 and PR-5 genes are homologous to SAR genes in tobacco and A. thaliana, and have close homologs in other monocots. As with tobacco, maize appears to have a family of PR-1 genes. These genes have putative leader sequences and hence it is likely that the encoded proteins accumulate extracellularly, similar to the situation in dicots.

PR-1, PR-5, and other SAR genes in tobacco and A. thaliana are coordinately induced by various treatments and in certain mutants. Necrotizing pathogens induce these genes in infected and systemic tissues, and this correlates with increased resistance in these tissues (Ward et al. 1991). In both species the inducer chemicals BTH, INA, and SA also induce these genes (Ward et al. 1991; Uknes et al. 1992; Vernooij et al. 1995; Friedrich et al. 1996; Lawton et al. 1996) and A. thaliana mutants that have constitutive disease resistance (such as lesion mimic plants when lesions are present) also express SAR genes constitutively (Lawton et al, 1993; Dietrich et al. 1994; Greenberg et al. 1994; Bowling et al. 1994; Weymann et al. 1995). Like the tobacco and A. thaliana genes, the maize PR-1 and PR-5 genes are also induced by pathogen infection, by inducing chemicals, and in lesion mimic plants (Fig. 4, lanes 6-10). Maize PR-1 is not only pathogen inducible in leaves but also appears to be inducible in roots (Gillikin et al. 1991) (we did not test for PR-5 induction in roots). These results show that expression of the maize PR-1 and PR-5 genes is closely associated with disease or states associated with disease resistance. As such, these maize defenserelated genes have many properties in common with dicot SAR genes. In contrast, the basic maize PR-1 gene described previously (Casacuberta et al. 1991) is not inducible in leaves by inducer chemicals (S. Morris, unpublished observations).

It is unknown whether the maize PR-1 and PR-5 genes can be induced systemically following local pathogen infection. If they were found to be systemically inducible, then these genes could functionally be described as SAR genes.

Interestingly, BTH-induced, defense-related gene expression in maize appears to be transient, with RNA levels going down to background levels at approximately 10 days after treatment. This mirrors BTH-induced gene expression in wheat, although BTH-induced disease resistance in wheat lasts the entire growing season (Görlach et al. 1996). In con- 
trast, SAR gene expression in tobacco remains elevated for longer periods (for at least 3 weeks), whereas the situation in A. thaliana is intermediate (Friedrich et al. 1996; Lawton et al. 1996). We did not test the duration of BTH-induced resistance in maize against downy mildew.

\section{PR-1 and PR-5: indicators of the resistance reaction.}

As shown in Figures 6-8, the maize PR-1 and PR-5 genes are inducible by pathogen infection. Incompatible and compatible pathogens induce PR-1 and PR-5 gene expression in a manner analogous to that observed in dicots (De Wit and van der Meer 1986). In incompatible interactions (i.e., IN2 infection of Rpl-A and Rpl-D plants and the described B. maydis infections) a strong increase in PR-1 and PR-5 gene expression is visible early in infection, around the time of onset of the HR. Gene expression subsequently declines in the strong incompatible reaction (e.g., IN2 on $R p 1-D$ ), or it levels off in the less resistant interaction, where lesions continue to spread (i.e., IN2 on Rp1-A- and B. maydis-infected plants). This time course of defense-related gene expression correlates with the paradigm that in an incompatible interaction it is the speed and intensity of the defense reaction that determines resistance to the pathogen (De Wit and van der Meer 1986). The paradigm of compatible interactions also holds true for the susceptible rust-maize interaction in that defense-related gene expression increases to lower levels, and later in time compared with an incompatible interaction (e.g., all KS1-infected plants). A functional model holds that in the compatible interaction, the pathogen can outgrow the defense response, but it cannot in the incompatible interaction.

A corollary to this paradigm holds that PR-1 and PR-5 gene expression is a good indicator of the defense response. At the very least, our data indicate that PR gene expression levels in the rust-maize interaction correlate with the resistance response. A good example of this is evident from the comparison of the incompatible interaction between the IN2 isolate and $R p 1-D$ and $R p 1-A$ plants. $R p 1-D$ plants are more resistant to IN2 than are $R p 1-A$ plants, as evidenced by the timing of the HR and the actual arrest of lesion growth, resulting in smaller lesions in Rpl-D plants. The higher resistance of $R p 1$ $D$ is also reflected by the PR-1 and PR-5 gene expression pattern: in IN2-infected $R p 1-D$ plants, defense-related gene expression is induced faster than in IN2-infected $R p 1-A$ plants. After the fungus was localized in $R p 1-D$ tissue, PR-1 and PR-5 gene expression decreased. Presumably, when the fungus was localized in these plants, the HR lesion stopped expanding, few additional cells came in contact with the pathogen, and defense-related gene expression levels decreased. In contrast, $R p 1-A$-infected plants show a slightly delayed gene induction pattern and sustained high PR-1 and PR-5 gene expression levels. In these plants HR lesions developed later (possibly indicative of poorer recognition) and continued to expand (possibly indicating that the fungus continues to infect new cells), presumably resulting in induction of PR-1 and PR-5 gene expression in these cells (compare $R p 1-D$ and Rpl-A at $72 \mathrm{~h}$ in Figure 7).

\section{Gene expression and SA accumulation in maize lesion mimics.}

In A. thaliana, lesion mimic mutants display many characteristics of infected plants, including callose deposition and autofluorescence, enhanced disease resistance, induction of SAR gene mRNA levels, and elevated levels of SA. Many lesion mimic mutants are known in maize and at least some of these may be due to mutations in known resistance genes (Walbot et al. 1983; Johal et al. 1995; Hu et al. 1996). For instance, recombinants in the Rpl locus of maize are known to generate genes with specificities for new rust isolates, and occasionally such recombination leads to the generation of a lesion mimic line that is resistant to all rust isolates (Hu et al. 1996).

Here, we provide data of another type indicating a connection between lesion mimic and disease response phenotypes. We report that many maize lesion mimic mutants share several characteristics with $A$. thaliana lesion mimic mutants: they display HR-like lesions (Figs. 10 and 12), exhibit dramatically enhanced levels of PR-1 and PR-5 gene expression (Figs. 9 and 10) and, where investigated, show increased levels of free and conjugated SA (Fig. 11). A. thaliana lesion mimic mutants are disease resistant. The disease resistance phenotype in maize lesion mimics, however, has yet to be established, with the exception of the " $R P 1$ recombination lesion mimic" line that is resistant to all rust isolates (Hu et al. 1996). In one other monocot, barley, a lesion mimic phenotype (in certain mlo alleles) correlates with increased disease resistance. However, it is unclear if this disease resistance is due to constitutive expression of SAR or if it has another basis, such as cell wall strengthening (Jørgensen 1994; Wolters et al. 1993).

The cloning of the gene responsible for the lesion phenotype in the maize $l l s 1$ line has recently been reported (Gray et al. 1997). The lesions of this line resemble those induced by Cochliobolus carbonum, but nothing has been reported about disease resistance in this line. Similarly, nothing has been reported about the expression of defense-related gene expression or SA accumulation in lesioned $l l s 1$ plant tissue. Because the nature of the Llsl gene product (a presumed dioxygenase) also gives no clues about a possible involvement in disease resistance, its involvement in pathways such as those described here is unclear.

\section{A role for $\mathrm{SA}$ in maize disease resistance?}

In dicots, SA appears to be an essential part of the pathway leading to SAR (Gaffney et al. 1993; Delaney et al. 1994). Pathogen infection triggers the accumulation of endogenous SA in tobacco, A. thaliana, and cucumber (Malamy et al. 1990; Métraux et al. 1990, Uknes et al. 1993). In rice, SA levels are relatively high in many lines and are not inducible upon pathogen infection. However, a general correlation between SA levels and resistance to rice blast disease was noted (Silverman et al. 1995). Thus, the situation in maize appears to be more like that in dicots than in rice: total SA levels in uninfected plants are fairly low, and are induced strongly in infected plants (Fig. 11).

SA levels in lesion mimic mutant plants are also elevated after lesions develop (Fig. 11; and data not shown). The presence of disease (HR)-like lesions, PR-1 and PR-5 gene expression, and SA accumulation indicates similarity to A. thaliana lesion mimics. The $A$. thaliana mutants show an increased disease resistance phenotype. The importance of SA in induction of disease resistance in tobacco and A. thaliana has been clearly demonstrated by in planta expression of the nahG gene, which codes for an SA-degrading enzyme. These plants are incapable of manifesting SAR after an initial inducing infection and, moreover, have a general, increased susceptibility 
to a range of pathogens (Gaffney et al. 1993; Delaney et al. 1994; Friedrich et al. 1995). Expression of the $n a h G$ gene in monocots may help to elucidate the role of SA in monocot disease resistance as well.

\section{A disease resistance pathway shared between monocots and dicots.}

The picture that has emerged over the last few years is that several aspects of induced resistance and PR-1 and PR-5 gene expression are shared by dicots and monocots. We confirmed this for maize and extended the dicot-monocot induced resistance parallel further. Chemical activators of induced resistance are capable of providing disease resistance in both plant groups and we report that this includes inhibition of downy mildew disease on maize. Lesion mimics in A. thaliana show increased defense-related gene expression and elevated SA levels when lesions are present, and this paper documents for the first time the same phenomenon in monocot lesion mimic mutants. PR-1 and PR-5 gene expression is induced quickly and strongly in incompatible interactions and is induced in a delayed fashion in compatible interactions in both plant groups. Finally, SA is induced in diseased plant tissue in dicots. Here, we provide the first report of this same phenomenon in a monocot. These similarities reinforce the notion that monocots and dicots share a disease resistance pathway that is old on an evolutionary time scale.

The exciting recent progress toward understanding this pathway in dicots (Ryals et al. 1996) holds promise for further dissection of this pathway in maize.

\section{MATERIAL AND METHODS}

\section{Downy mildew disease assays.}

For the field test, maize seeds of a downy mildew susceptible line were treated with a slurry of BTH (CGA245,704) or Apron. BTH (a $25 \%$ active ingredient formulation) was used at concentrations of 1 to $8 \mathrm{~g}$ of formulation per $\mathrm{kg}$ of seed. Apron (a 35\% active ingredient formulation) was used at $3 \mathrm{~g}$ of formulated product per $\mathrm{kg}$ of seed. Treated seeds were planted in fields in Thailand that have high levels of natural downy mildew (Peronosclerospora sorghi) infestation. For each treatment, four replications were planted, each with 99 plants. Disease was rated 40 days after planting, by counting the number of plants with disease symptoms. The experiment was conducted twice. The values were analyzed by Duncan's $t$ test for significant differences at the $P=0.05$ level, using the SAS software package (SAS, Cary, NC).

For the greenhouse disease test, seed of the susceptible line sweet G-90 and the resistant line TAMU $601 * 6252$ were treated with BTH as described above. The seeds were planted in $15-\mathrm{cm}$ pots, plants were thinned to 7 plants per pot, and 4 pots were used per treatment (i.e., 28 plants per treatment). The experiment was a completely randomized design with three replications. Conidia were collected from P. sorghi pathotype 1 and applied to seedlings in a dew chamber according to Craig (1987). After inoculation, seedlings were returned to the greenhouse and rated 5 to 6 days later.

\section{cDNA isolation.}

A $\lambda$ Zap II (Clonetech, Palo Alto, CA) cDNA library was made from RNA isolated from maize leaves 3 and 7 days after
BTH treatment. To isolate a PR-1 maize cDNA, the library was screened with a polymerase chain reaction fragment derived from a barley PR-1 gene (Bryngelsson et al. 1994). A maize PR-5 cDNA was isolated by screening the library with the rice thaumatin cDNA (Reimmann and Dudler 1993). Hybridization conditions were at reduced stringency for the PR-5 cDNA isolation $\left(60^{\circ} \mathrm{C}\right.$ hybridization and washing), according to Church and Gilbert (1984). The cDNA inserts were cloned into the Bluescript plasmid (Stratagene, La Jolla, CA) and their sequences determined.

\section{Chemical application, tissue collection, and SA analysis.}

For the chemical induction experiments, seeds were planted in doubly autoclaved soil. Three- to 4 -week-old maize plants were spray treated with $1.2 \mathrm{mM} \mathrm{BTH}(1 \mathrm{mg} / \mathrm{ml}$ of a $25 \%$ active ingredient formulation), $50 \mathrm{mM} \mathrm{SA}$, or $1.3 \mathrm{mM}$ INA (1 $\mathrm{mg} / \mathrm{ml}$ of a $25 \%$ active ingredient formulation). Plant leaf tissue was collected at appropriate times, immediately placed on dry ice, and stored at $-80^{\circ} \mathrm{C}$ until further use. Determinations of SA and "total" SA levels (free SA plus glucose conjugated SA) levels were performed essentially as described (Uknes et al. 1993). Heavily lesioned tissue from Les 4 and diseased tissue harvested 7 days after pathogen infection were used for SA analysis.

\section{RNA isolation and Northern blot analysis.}

Total RNA was isolated from frozen tissue by phenol/ chloroform extraction, followed by lithium chloride precipitation (Lagrimini et al. 1987). RNA samples were size separated on a formaldehyde-agarose gel and blotted to a nylon membrane (GeneScreen Plus, NEN, Boston) as described by Ausubel et al. (1987). Equal sample loading was confirmed by ethidium bromide staining of the samples in the gel. Gel isolated maize PR-1 and -5 DNA fragments were ${ }^{32} \mathrm{P}$-labeled with a random prime kit (Life Technologies, Gaithersburg, MD). Blots were hybridized with these probes and washed at $65^{\circ} \mathrm{C}$ according to Church and Gilbert (1984). Hybridizing bands were quantitated by PhosphorImager (Molecular Dynamics, Sunnyvale, CA) analysis. All Northern blots were repeated at least once.

\section{$B$. maydis and $C$. graminicola inoculations.}

$B$. maydis and C. graminicola are the causal organisms of SCLB and anthracnose leaf blight. These fungi were grown on potato dextrose agar and oatmeal plates, respectively, under near UV light. Spores were harvested from sporulating plates, diluted in distilled water, and applied by spray treatment to 4to 6-week-old plants. B. maydis was applied at 2,500 spores $/ \mathrm{ml}$, whereas $C$. graminicola was applied at $10^{6}$ spores $/ \mathrm{ml}$. Control plants were sprayed with distilled water. Inoculated plants were incubated in a high humidity chamber overnight, after which they were moved into a growth chamber. Incubation conditions were 14-h days and temperatures of $28 / 22^{\circ} \mathrm{C}$ (day/night). Plant leaf samples were collected prior to inoculation and on various days after inoculation, or from control and infected plants.

\section{Rp1 plant stock.}

Plants were grown in a soil/peat mixture (3:1) in $38 \times 61 \times$ $8 \mathrm{~cm}$ flats and watered daily with a dilute fertilizer (20:20:20). Plants were grown in a growth chamber at a constant tem- 
perature of $25^{\circ} \mathrm{C}$ with a 16 -h daylength. The rust-susceptible inbred R168 (rpl) and two near-isogenic lines with $R p l-A$ and $R p 1-D$ were used in the experiments.

\section{Rp1 disease assay.}

Maize seedlings with three fully expanded leaves were inoculated with rust spores. To prevent cross-contamination, separate flats were used for inoculation with each rust isolate. Approximately $100 \mu \mathrm{l}$ of freshly collected uredospores was mixed with $900 \mu \mathrm{l}$ of talc and rubbed onto the third and fourth leaf. The seedlings were next incubated together in a humidity chamber for $16 \mathrm{~h}$, after which the flats were placed in the growth chamber. Inoculated leaves of two plants were harvested at various times after inoculation. Two different plants were harvested for each time point. Leaves of mockinoculated (talc-only) plants were also harvested.

\section{Lesion mimics.}

Maize lesion mimics were greenhouse grown and sampled prior to lesion formation, after lesion formation, and after anthesis. When lesions were present, only leaf tissue with lesions was harvested for analysis.

\section{Tissue staining.}

Maize tissue was placed in a container with lactophenol (10 $\mathrm{g}$ of phenol, $10 \mathrm{ml}$ of lactic acid, $10 \mathrm{ml}$ of glycerol, and $10 \mathrm{ml}$ of water), completely covered, and vacuum infiltrated for approximately $25 \mathrm{~min}$. Next, the tissue was boiled for approximately $5 \mathrm{~min}$ and left shaking overnight. Leaf material was next cleared overnight at room temperature in chloral hydrate and stained in a solution of $\mathrm{K}_{2} \mathrm{HPO}_{4}$ /aniline blue for 3 days. Stained leaves mounted in $70 \%$ glycerol were examined under UV epifluorescence (Dietrich et al. 1994).

\section{ACKNOWLEDGMENTS}

We thank R. Dudler (University of Zurich) for providing the rice thaumatin clone, M. G. Neuffer (University of Missouri) for seed of lesion mimics, A. Genez for communicating unpublished data, L. Castor and C. Naidoo for the B. maydis and C. graminicola isolates, Helmut Kessmann for BTH, and Greg Warren for advice on statistics. The excellent plant care of Sheila Sips and Greg Crawford, sequencing by Rosanne Novitzky, the logistical support of Willy Rüss, and camera help by Antonio Molina are gratefully acknowledged. We also appreciate the critical reading of the manuscript by John Salmeron, Urs Neuenschwander, Michelle Hunt, and Jörn Görlach.

\section{LITERATURE CITED}

Alexander, D., Goodman, R. M., Gut-Rella, M., Glascock, C., Weymann, K., Friedrich, L., Maddox, D., Ahl-Goy, P., Luntz, T., Ward, E., and Ryals, J. 1993. Increased tolerance to two oomycete pathogens in transgenic tobacco expressing pathogenesis-related protein 1a. Proc. Natl. Acad. Sci. USA 90:7327-7331.

Ausubel, F. M., Brent, R., Kingston, R. E., Moore, D. D., Seidman, J. G., Smith, J. A., and Struhl, K. 1987. Current Protocols in Molecular Biology. J. Wiley and Sons, New York.

Baker, C. J., and Orlandi, E. W. 1995. Active oxygen in plant pathogenesis. Annu. Rev. Phytopathol. 33:299-321.

Bowles, D. J. 1990. Defense-related proteins in higher plants. Annu. Rev. Biochem. 59:873-907.

Bowling, S. A., Guo, A., Cao, H., Gordon, A. S., Klessig, D. F., and Dong, X. 1994. A mutation in arabidopsis that leads to constitutive expression of systemic acquired resistance. Plant Cell 6:1845-1857.

Broglie, K., Chet, I., Holliday, M., Cressman, R., Biddle, P., Knowlton,
S., Mauvais, C. J., and Broglie, R. 1991. Transgenic plants with enhanced resistance to the fungal pathogen Rhizoctonia solani. Science 254:1194-1197.

Bryngelsson, T., Sommer-Knudsen, J., Gregersen, P. L., Collinge, D. B., Ek, B., and Thordal-Christensen, H. 1994. Purification, characterization, and molecular cloning of basic PR-1-type pathogenesis-related proteins from barley. Mol. Plant-Microbe Interact. 7:267-275.

Cao, H., Bowling, S. A., Gordon, S., and Dong, X. 1994. Characterization of an Arabidopsis mutant that is nonresponsive to inducers of systemic acquired resistance. Plant Cell 6:1583-1592.

Cao, H., Glazebrook, J., Clarke, J. D., Volko, S., and Dong, X. 1997. The Arabidopsis NPRI gene that controls systemic acquired resistance encodes a novel protein containing ankyrin repeats. Cell 88:57-63.

Casacuberta, J. M., Puigdomenech, P., and San Segundo, B. 1991. A gene coding for a basic pathogenesis-related (PR-like) protein from Zea mays. Molecular cloning and induction by a fungus (Fusarium moniliforme) in germinating maize seeds. Plant Mol. Biol. 16:517-536.

Chasan, R. 1995. SA: Source or signal for SAR? Plant Cell 7:1519-1521.

Church, G. M., and Gilbert, W. 1984. Genomic sequencing. Proc. Natl. Acad. Sci. USA 81:1991-1995.

Craig, J. 1987. Tiered temperature system for producing and storing conidia of Peronosclerospora sorghi. Plant Dis. 71:356-358.

Dangl, J., Dietrich, R., and Richberg, M. 1996. Death don't have no mercy: Cell death programs in plant-microbe interactions. Plant Cell 8:1793-1807.

De Wit, P. J. G. M., and van der Meer, F. E. 1986. Accumulation of the pathogenesis-related tomato leaf protein $\mathrm{P} 14$ as an early indicator of incompatibility in the interaction between Cladosporium fulvum (Syn. Fulvia fulva) and tomato. Physiol. Mol. Plant Pathol. 28:203-214.

Delaney, T., Friedrich, L., and Ryals, J. 1995. Arabidopsis signal transduction mutant defective in chemically and biologically induced disease resistance. Proc. Natl. Acad. Sci. USA. 92:6602-6606.

Delaney, T., Uknes, S., Vernooij, B., Friedrich, L., Weymann, K., Negrotto, D., Gaffney, T., Gut-Rella, M., Kessmann, H., Ward, E., and Ryals, J. 1994. A central role of salicylic acid in plant disease resistance. Science 266:1247-1250.

Dietrich, R. A., Delaney, T. P., Uknes, S. J., Ward, E. R., Ryals, J. A., and Dangl, J. L. 1994. Arabidopsis mutants simulating disease resistance response. Cell 77:565-577.

Frendo, P., Didierjean, L., Passelegue, E., and Burkard, G. 1992. Abiotic stresses induce a thaumatin-like protein in maize; cDNA isolation and sequence analysis. Plant Science 85:61-69.

Friedrich, L., Vernooij, B., Gaffney, T., Morse, A., and Ryals, J. 1995. Characterization of tobacco plants expressing a bacterial salicylate hydroxylase gene. Plant Mol. Biol. 29:959-968.

Friedrich, L., Lawton, K., Ruess, W., Masner, P., Specker, N., Gut Rella, M., Meier, B., Dincher, S., Staub, T., Uknes, S., Métraux, J.-P., Kessmann, H., and Ryals, J. 1996. A benzothiadiazole derivative induces systemic acquired resistance in tobacco. Plant J. 9:61-70.

Gaffney, T., Friedrich, L., Vernooij, B., Negrotto, D., Nye, G., Uknes, S., Ward, E., Kessmann, H., and Ryals, J. 1993. Requirement of salicylic acid for the induction of systemic acquired resistance. Science 261: 754-756.

Gillikin, J., Burkhart, W., and Graham, J. 1991. Complete amino-acid sequence of a polypeptide from Zea mays similar to the pathogenesisrelated-1 family. Plant Physiol. 96:1372-1375.

Görlach, J., Volrath, S., Knauf-Beiter, G., Hengy, G., Beckhove, U., Kogel, K.-H., Oostendorp, M., Staub, T., Ward, E., Kessmann, H., and Ryals, J. 1996. Benzothiadiazole, a novel class of inducers of systemic acquired resistance, activates gene expression and disease resistance in wheat. Plant Cell 8:629-643.

Gray, J., Close, P. S. , Briggs, S. P., and Johal, G. S. 1997. A novel suppressor of cell death in plants encoded by the Llsl gene of maize. Cell $89: 25-31$

Greenberg, J., Guo, A., Klessig, D., and Ausubel, F. 1994. Programmed cell death in plants: A pathogen-triggered response activated coordinately with multiple defense functions. Cell 77:551-563.

Hahn, M., Jungling, S., and Knogge, W. 1993. Cultivar-specific elicitation of barley defense reactions by the phytotoxic peptide NIP1 from Rhynchosporium secalis. Mol. Plant-Microbe Interact. 6:745-754.

Hu, G., Richter, T., Hulbert, S., and Pryor, T. 1996. Disease lesion mimicry caused by mutations in the rust resistance gene $R p 1$. Plant Cell 8: 1367-1376.

Hulbert, S. H., and Bennetzen, J. L. 1991. Recombination at the Rp1 
locus of maize. Mol. Gen. Genet. 226:377-382.

Huynh, Q., Borgmeyer, J., and Zobel, J. 1992. Isolation and characterization of a $22 \mathrm{kda}$ protein with antifungal properties from maize seeds. Biochem. Biophys. Res. Commun. 182:1-5.

Hwang, B. K., and Heitefuss, R. 1992. Induced resistance of spring barley to Erysiphe graminis f. sp. hordei. Phytopathol. Z. 103:41-47.

Johal, G., Hulbert, S., and Briggs, S. 1995. Disease lesion mimics of maize: A model for cell death in plants. BioEssays 17:685-692.

Jørgensen, J. H. 1994. Genetics of powdery mildew resistance in barley. Crit. Rev. Plant Sci. 13:97-119.

Kessmann, H., Staub, T., Hofmann, C., Ahl Goy, P., Ward, E., Uknes, S., and Ryals, J. 1993. Induced disease resistance by isonicotinic acid derivatives. Jpn. J. Pestic. Sci. 10:29-37.

Kessmann, H., Staub, T., Hofmann, C., Maetzke, T., Herzog, J., Ward, E., Uknes, S., and Ryals, J. 1994. Induction of systemic acquired resistance in plants by chemicals. Annu. Rev. Phytopathol. 32:439-59.

Kogel, K., Beckhove, U., Dreschers, J., Munch, S., and Romme, Y. 1994. Acquired resistance in barley. Plant Physiol. 106:1269-1277.

Kuc, J. 1982. Induced immunity to plant disease. BioScience 32:854860.

Lagrimini, L. M., Burkhart, W., Moyer, M., and Rothstein, S. 1987. Molecular cloning of complementary DNA encoding the ligninforming peroxidase from tobacco: Molecular analysis and tissuespecific expression. Proc. Natl. Acad. Sci. USA 84:7542-7546.

Lawton, K., Friedrich, L., Hunt, M., Weymann, K., Delaney, T., Kessmann, H., Staub, T., and Ryals, J. 1996. Benzothiadiazole induces disease resistance in arabidopsis by activation of the systemic acquired resistance signal transduction pathway. Plant J. 10:71-82.

Lawton, K., Uknes, S., Friedrich, L., Gaffney, T., Alexander, D., Goodman, R., Métraux, J.-P., Kessmann, H., Ahl-Goy, P., Gut Rella, M., Ward, E., and Ryals, J. 1993. The molecular biology of systemic acquired resistance. Pages 410-420 in: Mechanisms of Defence Responses in Plants. B. Fritig and M. Legrand, eds. Kluwer, Dordrecht, The Netherlands.

Lawton, K., Weymann, K., Friedrich, L., Vernooij, B., Uknes, S., and Ryals, J. 1995. Systemic acquired resistance in Arabidopsis requires salicylic acid but not ethylene. Mol. Plant-Microbe Interact. 8:863870.

Lin, K.-C., Bushnell, W. R., Szabo, L. J., and Smith, A. G. 1996. Isolation and expression of a host response gene family encoding thaumatin-like proteins in incompatible oat-stem rust fungus interactions. Mol. Plant-Microbe Interact. 9:511-522.

Malamy, J., Carr, J. P., Klessig, D. F., and Raskin, I. 1990. Salicylic acid: A likely endogenous signal in the resistance response of tobacco to viral infection. Science 250:1002-1004.

Mehdy, M. 1994. Active oxygen species in plant defense against pathogens. Plant Physiol. 105:467-472.

Métraux, J.-P., Ahl-Goy, P., Staub, T., Speich, J., Steinemann, A., Ryals, J., and Ward, E. 1991. Induced systemic resistance in cucumber in response to 2,6-dichloro-isonicotinic acid and pathogens. Pages 432439 in: Advances in Molecular Genetics of Plant-Microbe Interactions. Vol. 1. H. Hennecke and D. P. S. Verma, eds. Kluwer, Dordrecht, The Netherlands.

Métraux, J.-P., Signer, H., Ryals, J., Ward, E., Wyss-Benz, M., Gaudin, J., Raschdorf, K., Schmid, E., Blum, W., and Inverardi, B. 1990. Increase in salicylic acid at the onset of systemic acquired resistance in cucumber. Science 250:1004-1006.

Mölders, W., Buchala, A., and Métraux, J.-P. 1996. Transport of salicylic acid in tobacco necrosis virus-infected cucumber plants. Plant Physiol. 112:787-792.

Oerke, E.-C., Dehne, H.-W., Schönbeck, F., and Weber, A. 1994. Crop Production and Crop Protection. Elsevier Science B. V., Amsterdam.

Pallas, J. A., Paiva, N. L., Lamb, C., and Dixon, R. A. 1996. Tobacco plants epigenetically suppressed in phenylalanine ammonia-lyase expression do not develop systemic acquired resistance in response to infection by tobacco mosaic virus. Plant J. 10:281-293.

Payne, G., Middlesteadt, W., Williams, S., Desai, N., Parks, T. D., Dincher, S., Carnes, M., and Ryals, J. 1988. Isolation and nucleotide sequence of a novel cDNA clone encoding the major form of pathogenesis-related protein R. Plant Mol. Biol. 11:223-224.

Pfitzner, U. M., and Goodman, H. M. 1987. Isolation and characterization of cDNA clones encoding pathogenesis-related proteins from tobacco mosaic virus infected tobacco plants. Nucleic Acid Res. 15: $4449-4465$
Rasmussen, J. B., Hammerschmidt, R., and Zook, M. N. 1991. Systemic induction of salicylic acid accumulation in cucumber after inoculation with Pseudomonas syringae pv syringae. Plant Physiol. 97:1342-1347.

Rebmann, G., Mauch, F., and Dudler, R. 1991. Sequence of a wheat cDNA encoding a pathogen-induced thaumatin-like protein. Plant Mol. Biol. 17:283-285.

Reimmann, C., and Dudler, R. 1993. cDNA cloning and sequence analysis of a pathogen-induced thaumatin-like protein from rice (Oryza sativa). Plant Physiol. 101:1113-1114.

Richardson, M., Valdes-Rodriquez, S., and Blanco-Labra, A. 1987. A possible function for thaumatin and a TMV-induced protein suggested by homology to a maize inhibitor. Nature 327:432-434.

Ross, A. F. 1961a. Localized acquired resistance to plant virus infection in hypersensitive hosts. Virology 14:329-339.

Ross, A. F. 1961b. Systemic acquired resistance induced by localized virus infections in plants. Virology 14:340-358.

Ryals, J., Neuenschwander, U., Willits, M., Molina, A., Steiner, H.-Y., and Hunt, M. 1996. Systemic acquired resistance. Plant Cell 8:1809-1819.

Ryals, J., Uknes, S., and Ward, E. 1994. Systemic acquired resistance. Plant Physiol. 104:1109-1112.

Ryals, J., Weymann, K., Lawton, K., Friedrich, L., Ellis, D., Steiner, H.Y., Johnson, J. Delaney, T. P., Jesse, T., Vos, P., and Uknes, S. 1997. The Arabidopsis thaliana NIM1 protein is homologous to the mammalian transcription factor inhibitor IKB. Plant Cell 9:425-439.

Shulaev, V., Leon, J., and Raskin, I. 1995. Is salicylic acid a translocated signal of systemic acquired resistance? Plant Cell 7:1691-1701.

Silverman, P., Saskar, M., Kanter, D., Schweizer, P., Métraux, J.-P., and Raskin, I. 1995. Salicylic acid in rice - biosynthesis, conjugation, and possible role. Plant Physiol. 108:633-639.

Smith, J. A., and Métraux, J.-P. 1991. Pseudomonas syringae pv. syringae induces systemic resistance to Pyricularia oryzae in rice. Physiol. Mol. Plant Pathol. 39:451-461.

Uknes, S., Mauch-Mani, B., Moyer, M., Williams, S., Dincher, S., Chandler, D., Potter, S., Slusarenko, A., Ward, E., and Ryals, J. 1992. Acquired resistance in Arabidopsis. Plant Cell 4:645-656.

Uknes, S., Morris, S., Vernooij, B., and Ryals, J. 1996. The role of benzoic acid derivatives in systemic acquired resistance. Pages 253-263 in: Recent Advances in Phytochemistry. Vol. 30. Phytochemical Diversity and Redundancy in Ecological Interactions. J. T. Romeo, J. A. Saunders, and P. Barbosa, eds. Plenum, New York.

Uknes, S., Winter, A. M., Delaney, T., Vernooij, B., Morse, A., Friedrich, L., Nye, G., Potter, S., Ward, E., and Ryals, J. 1993. Biological induction of systemic acquired resistance in Arabidopsis. Mol. PlantMicrobe Interact. 6:692-698.

Vernooij, B., Friedrich, L., Ahl Goy, P., Staub, T., Kessmann, H., and Ryals, J. 1995. 2,6,-Dichloroisonicotinic acid-induced resistance to pathogens without the accumulation of salicylic acid. Mol. PlantMicrobe Interact. 8:228-234

Vernooij, B., Friedrich, L., Morse, A., Reist, R., Kolditz-Jowhar, R., Ward, E., Uknes, S., Kessmann, H., and Ryals, J. 1994. Salicylic acid is not the translocated signal responsible for inducing systemic acquired resistance but is required in signal transduction. Plant Cell 6: 959-965.

Von Heijne, G. 1986. A new method for predicting signal sequence cleavage sites. Nucleic Acids Res. 14:4683-4690.

Walbot, V., Hoisington, D., and Neuffer, M. 1983. Disease lesion mimic mutations. Pages 431-441 in: Genetic Engineering of Plants. T. Kosuge, C. Meredith, and A. Hollaender, eds. Plenum, New York.

Ward, E. R., Uknes, S. J., Williams, S. C., Dincher, S. S., Wiederhold, D. L., Alexander, D. C., Ahl-Goy, P., Métraux, J.-P., and Ryals, J. A. 1991. Coordinate gene activity in response to agents that induce systemic acquired resistance. Plant Cell 3:1085-1094.

Wasternack, C., Atzora, R., and Kogel, K. H. 1993. Induction of a thionin, the jasmonate-induced $6 \mathrm{kDa}$ protein of barley by 2,6dichloroisonicotinic acid. J. Phytopathol. 140: 280-284.

Weymann, K., Hunt, M., Uknes, S., Neuenschwander, U., Lawton, K., Steiner, H., and Ryals, J. 1995. Suppression and restoration of lesions formation in Arabidopsis mutants. Plant Cell 7:2013-2022.

White, R. F. 1979. Acetylsalicylic acid (aspirin) induces resistance to tobacco mosaic virus in tobacco. Virology 99:410-412.

Wolters, M., Hollricher, K., Salamini, F., and Schulze-Lefert, P. 1993. The mlo resistance alleles to powdery mildew infection in barley trigger a developmentally controlled defence mimic phenotype. Mol. Gen. Genet. 239:122-128. 